ANDREW HYNES SERIES: TECTONIC PROCESSES

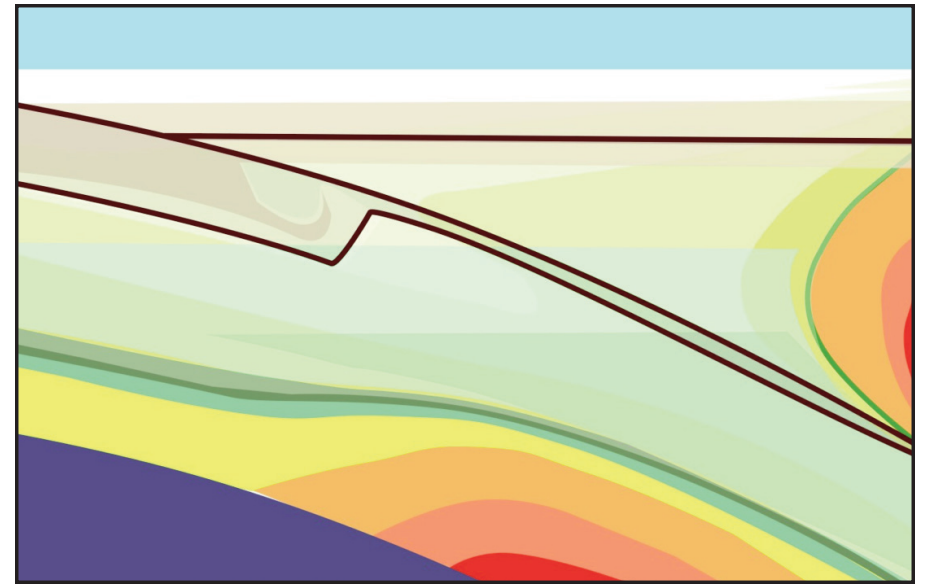

\section{Age, Geochemistry and Origin of the Ardara Appinite Plutons, Northwest Donegal, Ireland}

J. Brendan Murphy, ${ }^{1,4}$ R. Damian Nance ${ }^{2}$, Logan B. Gabler $^{2}$, Alexandra Martell ${ }^{1}$, and Douglas A. Archibald ${ }^{3}$

${ }^{1}$ Department of Earth Sciences, St. Francis Xavier University

Antigonish, Nova Scotia, B2G 2W5, Canada

E-mail:bmurpby@stfx.ca

${ }^{2}$ Department of Geological Sciences, Obio University

316 Clippinger Laboratories, Athens, Obio 45701, U.S.A.

${ }^{3}$ Department of Geological Sciences and Geological Engineering Queen's University, Kingston, Ontario, K7L 3N6, Canada

${ }^{4}$ Earth Dynamics Research Group

ARC Centre of Excellence for Core to Crust Fluid Systems (CCFS) and The Institute for Geoscience Research (TIGeR), School of Earth and Planetary Sciences

Curtin University, Bentley, Perth, Western Australia 6102, Australia

\section{SUMMARY}

In northwest Donegal, Ireland, a large number of coeval appinitic (hornblende-plagioclase-rich) plutons and lamprophyre dykes occur around the Ardara pluton, a granitic satellite body and one of the oldest phases of the ca. 428-400 Ma composite Donegal Batholith. The appinite units form a bimodal (mafic-felsic) suite in which hornblende is the dominant mafic mineral and typically occurs as large prismatic phenocrysts within a finer grained matrix. Lamprophyre dykes are mafic in composition with a geochemistry that is very similar to that of the mafic appinite bodies. Both mafic rocks are subalkalic, with calc-alkalic and tholeiitic tendencies, and show trace element abundances indicating that the mantle source was contaminated by subduction zone fluids. ${ }^{40} \mathrm{Ar} /{ }^{39} \mathrm{Ar}$ analysis of hornblende separated from two samples of appinite yield mid-Silurian (434.2 $\pm 2.1 \mathrm{Ma}$ and $433.7 \pm 5.5 \mathrm{Ma}$ ) cooling ages that are interpreted to closely date the time of intrusion. Hence, according to the available age data, the appinite bodies slightly predate, or were coeval with, the earliest phases of the Donegal Batholith. Sm-Nd isotopic analyses yield a range of initial $\varepsilon N d$ values ( +3.1 to -4.8 at $t=435 \mathrm{Ma}$ ) that, together with trace element data, indicate that the appinitic magmas were likely derived from melting of metasomatized sub-continental lithospheric mantle and/or underplated mafic crust, with only limited crustal contamination during magma ascent. The appinitic intrusions are interpreted to have been emplaced along deep-seated crustal fractures that allowed for mafic and felsic magma to mingle. The magmas are thought to be the products of collisional asthenospheric upwelling associated with the closure of Iapetus and the ensuing Caledonian orogeny, either as a result of an orogen-wide delamination event or as a consequence of more localized slab break-off.

\section{RÉSUMÉ}

Dans le nord-ouest du Donegal, en Irlande, un grand nombre de plutons appinitiques (riches en hornblendes ou en plagioclases) et de dykes de lamprophyres contemporains se retrouvent autour du pluton d'Ardara, un corps satellite granitique et l'une des phases les plus anciennes du batholite composite de Donegal, âgé d'environ 428-400 Ma. Les unités de l'appinite forment une suite bimodale (mafique-felsique) dans laquelle la hornblende est le minéral mafique dominant et se présente généralement sous forme de grands phénocristaux prismatiques au sein d'une matrice à grains plus fins. Les dykes de lamprophyres ont une composition mafique dont la géochimie est très similaire à celle des corps d'appinite mafique. Les deux roches mafiques sont subalcaliques, avec des tendances calcoalcalines et tholéiitiques, et elles montrent des teneurs en élé-

Geoscience Canada, v. 46, http://www.dx.doi.org/10.12789/geocanj.2019.46.144 pages 31-48 $\quad$ C 2019 GAC/AGC® 
ments traces indiquant que la source du manteau a été contaminée par des fluides de zone de subduction. L'analyse ${ }^{40} \mathrm{Ar} /{ }^{39} \mathrm{Ar}$ des hornblendes provenant de deux échantillons d'appinite donne des âges de refroidissement du Silurien moyen (434,2 $\pm 2,1 \mathrm{Ma}$ et 433,7 \pm 5,5 Ma) qui sont interprétés comme étant proches de la date de l'intrusion. Par conséquent, selon les données d'âge disponibles, les corps d'appinite sont légèrement antérieurs ou contemporains des toutes premières phases du batholite de Donegal. Les analyses isotopiques Sm$\mathrm{Nd}$ aboutissent à une gamme de valeurs $\varepsilon \mathrm{Nd}$ initiales $(+3,1$ à 4,8 à $\mathrm{t}=435 \mathrm{Ma}$ ) qui, associées aux données des éléments traces, indiquent que les magmas appinitiques sont probablement dérivés de la fusion d'un manteau lithosphérique souscontinental métasomatisé et / ou d'une croûte mafique sousplaquée, avec une contamination crustale limitée lors de l'ascension du magma. Les intrusions appinitiques sont interprétées comme s'étant mises en place le long de fractures profondes de la croûte qui ont permis au magma mafique et au magma felsique de se mélanger. On pense que les magmas sont les produits de la remontée (upwelling) asthénosphérique collisionnelle associée à la fermeture de l'océan Iapetus et à l'orogenèse calédonienne qui s'ensuit, soit à la suite d'un délaminage à l'échelle de l'orogène, soit à la suite d'une rupture plus localisée de la plaque.

Traduit par la Traductrice

\section{INTRODUCTION}

In many parts of the Caledonian orogenic belt of Scotland and Ireland, major granitoid bodies, such as the composite Donegal Batholith in NW Ireland, are associated with a distinct suite of relatively small, hornblende-rich plutons formed from water-rich magmas that are 'peri-batholithic' in that they occur around the periphery of the composite batholith (Pitcher and Berger 1972). Known collectively as the appinite suite after the district of Appin in Scotland (e.g. Walker 1927; Bowes and McArthur 1976; Hamidullah and Bowes 1987), these intrusive rocks, which range from mafic to felsic in composition, are unusual in their mineralogy and texture. Those of mafic composition are medium- to coarse-grained melanocratic rocks composed of large, idiomorphic hornblende crystals in a matrix of feldspar and minor quartz (e.g. Pitcher and Berger 1972; Wright and Bowes 1979). Those of intermediate to felsic composition are also rich in idiomorphic hornblende and include syenite, monzonite, diorite and granodiorite. The suite is also characterized by the widespread occurrence of associated breccia intrusions and brecciated metasedimentary rocks.

The appinite suite in both Scotland and Donegal is commonly associated with lamprophyre dykes that show a similar peri-batholithic relationship with respect to major granitoid batholiths (Atherton and Ghani 2002). This temporal and spatial association has been widely interpreted to reflect a genetic linkage between the appinite suite, the lamprophyre dykes and the granitoid batholiths (e.g. Pitcher and Berger 1972), all of which were collectively emplaced towards the end of the Scandian orogeny (e.g. Siegesmund and Becker 2000; Atherton and Ghani 2002).
In Ireland, appinite bodies comprise a sub-group of Caledonian igneous intrusions best exposed around the Ardara pluton at the southwestern end of the composite Donegal Batholith (Fig. 1). The Ardara pluton is one of several intrusive bodies emplaced along the periphery of the Main Donegal Granite (Pitcher and Berger 1972). Available geochronological data suggest that the composite Donegal Batholith contains discrete phases ranging in age from 428 to $400 \mathrm{Ma}$ and that the Ardara pluton is among the oldest of these phases (Condon et al. 2004).

In the Scottish Caledonides, rocks of the appinite suite are also spatially and temporally associated with 430-408 Ma granitoid magmatism (e.g. Neilson et al. 2009). These appinite plutons are geochemically distinct from coeval mafic and granitoid rocks of other associations (Fowler and Henney 1996; Atherton and Ghani 2002). They are typically calc-alkaline and have compositional affinities with shoshonite (basaltic, K-rich trachyandesite composed of olivine, augite and plagioclase phenocrysts), features suggesting emplacement in a volcanic arc tectonic setting (Thompson and Fowler 1986; Macdonald et al. 1986; Fowler 1988). Their distinctive geochemistry and the timing of their emplacement (broadly synchronous with arc-continent collision) has been interpreted to reflect melting of a previously metasomatized lithospheric mantle as a consequence of slab break-off following the termination of subduction (e.g. Atherton and Ghani 2002; Ghani and Atherton 2008; Neilson et al. 2009; Cooper et al. 2013). In addition, recent proposals that large batholiths preferentially form during the waning stages of collision and consequent slab failure (Hildebrand and Whalen 2014a, b; Hildebrand et al. 2018) indicate that rocks of the appinite suite have the potential of contributing significantly to our understanding of collisional processes and the voluminous granitoid magmas with which they are associated.

Despite their potential importance to understanding the genesis and tectonic setting of the Caledonian intrusive rocks, published geochemical data for the appinitic rocks of Donegal are sparse and include only a limited suite of petrogenetically indicative trace elements (e.g. French 1966; Hall 1967), and the precise age of their intrusion is unknown. To further our understanding of these enigmatic rocks and their association with voluminous granitoid batholiths, this paper aims to clarify the intrusive age and petrogenesis of this suite through geochronological $\left({ }^{40} \mathrm{Ar} /{ }^{39} \mathrm{Ar}\right.$ on hornblende), geochemical and isotopic $(\mathrm{Sm}-\mathrm{Nd})$ analysis of the appinite bodies associated with the Ardara pluton.

\section{GEOLOGICAL SETTING}

The Donegal Batholith of NW Ireland (Fig. 1), made famous by the classical work of Pitcher and Berger (1972), is made up of a suite of Caledonian granitic plutons emplaced into Laurentian crust in the mid-Silurian-early Devonian (428-400 Ma, U/Pb: Condon et al. 2004; 418-397 Ma, Rb/Sr: Halliday et al. 1980; O'Connor et al. 1982, 1987), during the final closure of the Iapetus Ocean (Ghani and Atherton 2008). During the development of the Caledonian orogen, the Laurentian margin 


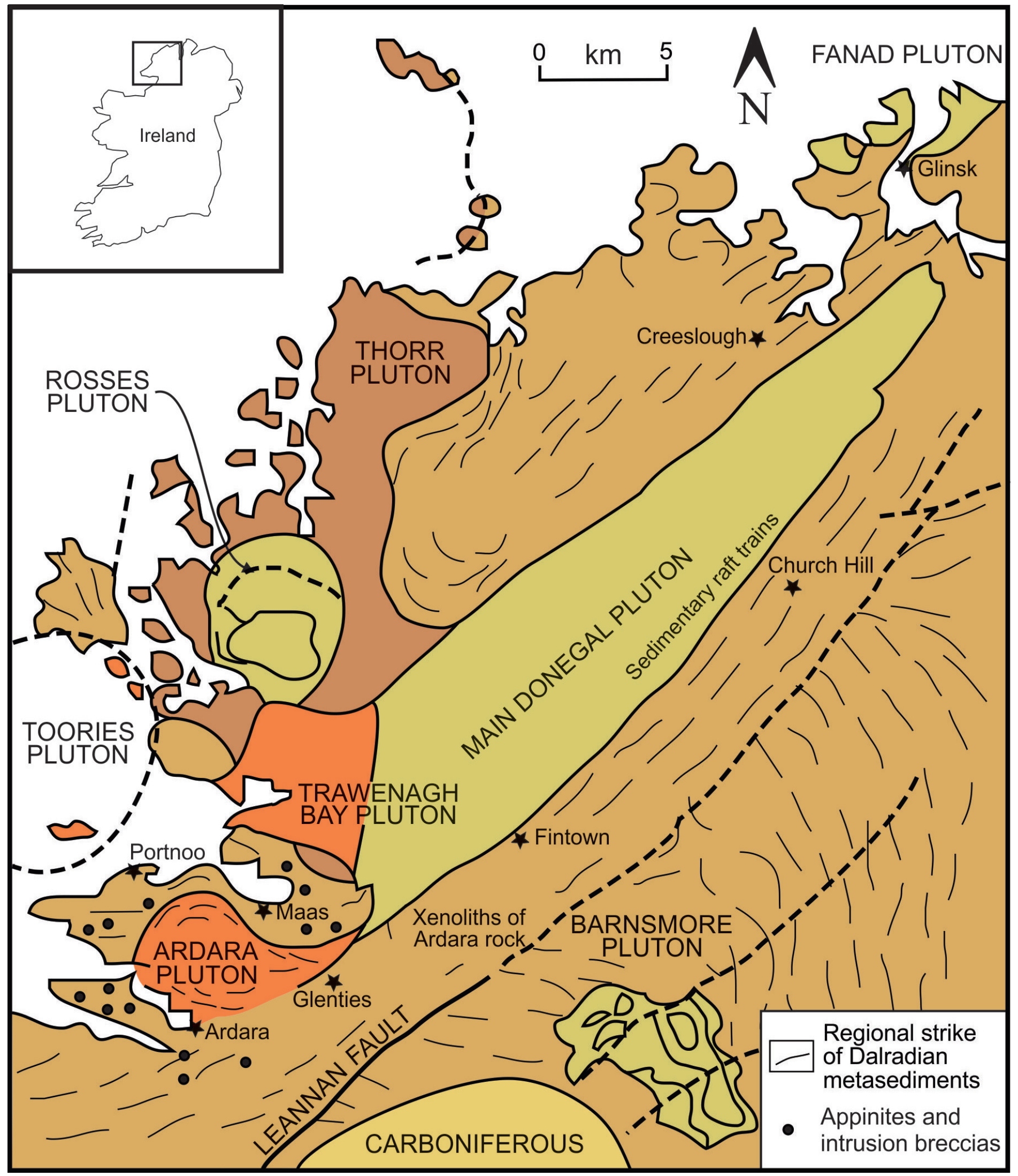

Figure 1. Simplified geological map of the composite Donegal Batholith in northwest Ireland (from Ghani and Atherton 2008). 
was affected by two distinct orogenic episodes (e.g. van Staal et al. 1998). The first was the short-lived, mid-Ordovician Grampian event (Dewey and Shackleton 1984; Oliver 2001; Chew and Strachan 2014) linked to arc formation and accretion associated with the subduction of Iapetus oceanic lithosphere below the Laurentian margin at ca. 470-460 Ma. The second and main episode records the final closure of Iapetus and the collision of the Laurentia margin with Baltica-Ganderia (Scandian orogeny) and Avalonia (Acadian orogeny) in midSilurian to early Devonian time (e.g. Condon et al. 2006; Chew and Strachan 2014). In Ireland, the resulting Iapetus suture strikes NE-SW from Clogherhead in County Louth to the Dingle Peninsula in County Kerry. Ireland's crust northwest of this suture was originally derived from Laurentia, whereas the crust to the southeast comprises terranes that were originally derived from Gondwana (Todd et al. 1991).

The Donegal Batholith is a composite, predominantly granitoid body made up of the Thorr, Fanad, Trawenagh Bay, Rosses, Barnesmore, Toories and Ardara plutons in addition to the Main Donegal Batholith (Pitcher and Berger 1972; Vernon and Patterson 1993) (Fig. 1). These plutons were emplaced into the Dalradian Supergroup country rock at mid-crustal levels (Siegesmund and Becker 2000) and display distinct differences regarding their shape, internal structures, contact aureoles and emplacement mechanisms. The Dalradian Supergroup itself was deposited along the eastern margin of Laurentia during the late Neoproterozoic and early Cambrian and comprises a thick sequence of lithologically diverse metasedimentary and mafic volcanic rocks (Ghani and Atherton 2008). Dalradian lithologies in Donegal include mica schist, dolomitic schist, and striped and banded siliceous quartzite (Ghani and Atherton 2008).

The Main Donegal Granite (MDG) is the largest pluton within the Donegal Batholith, forming an elongate, steepwalled body with sharp margins that cross-cut intensely deformed Dalradian polymetamorphic schist, quartzite and metabasite (Pitcher and Read 1960; Hutton 1982; Stevenson et al. 2008). Although predominantly granitic, the MDG is internally sheared and varies from mafic to felsic in composition. It is characterized by a foliation and contains inclusions of Dalradian country rock oriented parallel to the length of the pluton (Berger 1971). These features are reportedly the result of stresses superimposed upon the pluton after its emplacement but before complete cooling and consolidation had occurred (French 1976; Hutton and Alsop 1996). The high-K, calc-alkaline granite and granodiorite that make up the MDG are thought to have been emplaced during a phase of major NESW sinistral strike-slip faulting that characterizes the final phase of Iapetus closure in the British Caledonides (Atherton and Ghani 2002). The MDG is temporally and spatially associated with both lamprophyre dykes and appinite bodies, the latter being most common adjacent to the Ardara pluton at its southwestern margin (Fig. 1).

\section{Ardara Pluton}

Marginal to the MDG, but also contributing to xenoliths within it (Price 1997), the smaller Ardara pluton is a concentrically zoned granodiorite-quartz monzodiorite body (Fig. 2), the outer zone of which is quite strongly deformed (French 1966; Vernon and Patterson 1993). It is a complex, roughly circular body about $10 \mathrm{~km}$ in diameter and exhibits sharp contact zones (French 1966). During emplacement, the metasedimentary Dalradian host rocks underwent contact metamorphism and ductile deformation, the latter thought to have provided most of the space for the pluton (Siegesmund and Becker 2000). There were three phases of intrusion; an early outer zone of quartz diorite, an inner zone of coarse potassiumfeldspar megacrystic granodiorite and a later core composed of equigranular granodiorite. Unpublished $\mathrm{U} / \mathrm{Pb}$ data for the Ardara pluton date its intrusion ca. $427 \mathrm{Ma}$ (Condon et al. 2004).

The Ardara pluton has been regarded as a classic example of emplacement by expansion (ballooning) due to the injection of significant volumes of magma into the centre of the body after initial intrusion (Pitcher and Berger 1972). The bulk of the foliation within the pluton is magmatic (apart from a thin rind of solid-state deformation), suggesting that the expansion was accompanied by magmatic flow (Harmon et al. 1984). Flattened microgranitoid enclaves, concentric magmatic flow foliation, and compositional zoning within the pluton are consistent with expansion of magma prior to crystallization (Vernon and Patterson 1993). Mafic enclaves with variable modes of occurrence and texture resemble the lithologies in the appinitic intrusions. Some enclaves within the pluton were sufficiently rigid to fragment without any field evidence of mixing or mingling (Atherton and Ghani 2002). These field relationships suggest the intrusion of appinitic magmas preceded the Ardara pluton, although there may be some temporal overlap between early stages of pluton emplacement and the lamprophyre dykes (Atherton and Ghani 2002).

\section{Appinite Suite}

The Ardara pluton is surrounded by a large number of small appinitic intrusions and associated lamprophyre dykes, which are also thought to have been intruded during the final stages of the Caledonian orogeny (Atherton and Ghani 2002). The rocks of appinitic intrusions constitute the appinite suite and are most commonly found in small stocks, sheets, bosses and dykes, commonly closely associated with late to post-tectonic granitoid intrusions (e.g. Fowler and Henney 1996). The suite primarily occurs along the southern edge of the MDG and within $3 \mathrm{~km}$ of the Ardara pluton, where it additionally forms small irregular pipes or vents, clustered in large numbers around the plutons and as mafic enclaves within them.

Rocks of the appinite suite are typically coarse-grained and porphyritic with green to brown hornblende in a groundmass with approximately equal proportions of plagioclase and potassium-feldspar (Hall 1967). The appinitic intrusions are predominantly lenticular masses, $100-550 \mathrm{~m}$ in width, and most have irregular margins (French 1966) with steeply inclined contacts that truncate regional Dalradian structures and related foliations. Several appinitic masses north of the pluton exhibit a foliation defined by the alignment of felsic minerals interpreted to have formed during their emplacement 


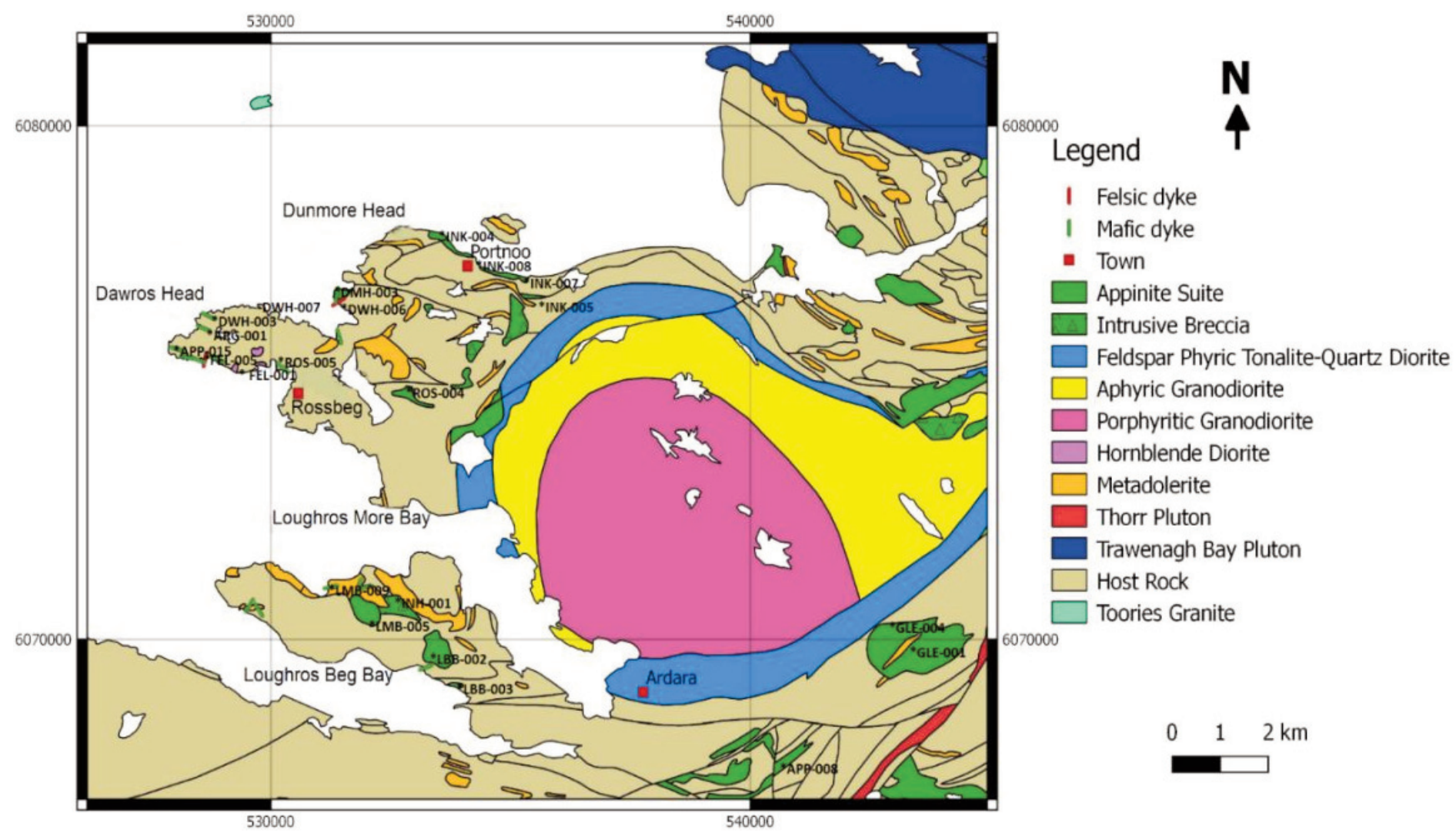

Figure 2. Geological map of the Ardara pluton showing sample locations (after Geological Survey of Ireland 2014). See Table 1 for details of locations.

and cooling (Bowes and McArthur 1976). The presence of xenoliths of appinitic rocks and lamprophyre within the MDG suggests that both were intruded prior to the emplacement of this pluton (French 1976). However, while the Ardara pluton has an early marginal phase lithologically identical to one of the rocks of the appinite suite, and both the appinitic intrusions and lamprophyre dykes crop out close to the pluton, neither cut the pluton itself (French 1976).

Many appinitic bodies are accompanied, particularly along their margins and in roof zones, by masses of disrupted metasedimentary rocks interpreted as intrusion breccias (French 1966). These breccia masses occur in near-vertical conduits that are elliptical in cross section with long axes up to $12 \mathrm{~m}$. The clasts in the breccia are inferred to have been transported upwards to their present positions and comprise fragments of carbonate and quartzitic rocks that are typical of the Dalradian host rock (French 1966).

The appinite suite is made up of coeval plutonic and hypabyssal rocks that range from mafic (gabbro) to intermediate-felsic (diorite, granodiorite) in composition and contain prismatic hornblende in a groundmass of plagioclase, with or without quartz (Fig. 3a, b). The hornblende crystals are typically $3-5 \mathrm{~mm}$ in length and, in some cases, are in grain boundary contact with each other.

Although mingling of felsic and mafic lithologies within the appinite suite is rare, some local evidence of hybridization has been observed (Hall 1967). The relationship between the different lithologies is complex with evidence for multiple intrusion and in situ differentiation, as well as complex interactions with the surrounding country rock (Platten 1991). Pitcher and Berger (1972) observed that some outcrops are dominated by intrusion breccia and explosion breccia characterized by angular fragments of quartzite and calc-silicate rock within an appinitic matrix. These features, together with the dominance of hornblende and the wide range of textures, suggest that crystallization of the appinitic magmas occurred under high water vapour pressure (Rock 1991).

\section{Lamprophyre Dykes}

The rocks of the appinite suite, along with the breccia intrusions associated with them, intrude and are intruded by lamprophyre dykes (Elsdon and Todd 1989). Lamprophyre (Fig. 3c) occurs as dykes and sills that intruded the Dalradian host rocks and is characterized by phenocrysts of hornblende and phlogopite with lesser amounts of clinopyroxene. The groundmass is diverse and includes plagioclase, biotite, pyroxene and amphibole. Lamprophyre variants include hornblendite, consisting mostly of idiomorphic hornblende within a relatively fine-grained matrix dominated by plagioclase. Less commonly, lamprophyre also contains interstitial quartz (Pitcher and Berger 1972).

\section{${ }^{40} \mathrm{Ar} /{ }^{39} \mathrm{Ar}$ THERMOCHRONOLOGY}

\section{Analytical Methods}

In order to date the emplacement of the Ardara appinite suite, ${ }^{40} \mathrm{Ar} /{ }^{39} \mathrm{Ar}$ thermochronology was performed at the 

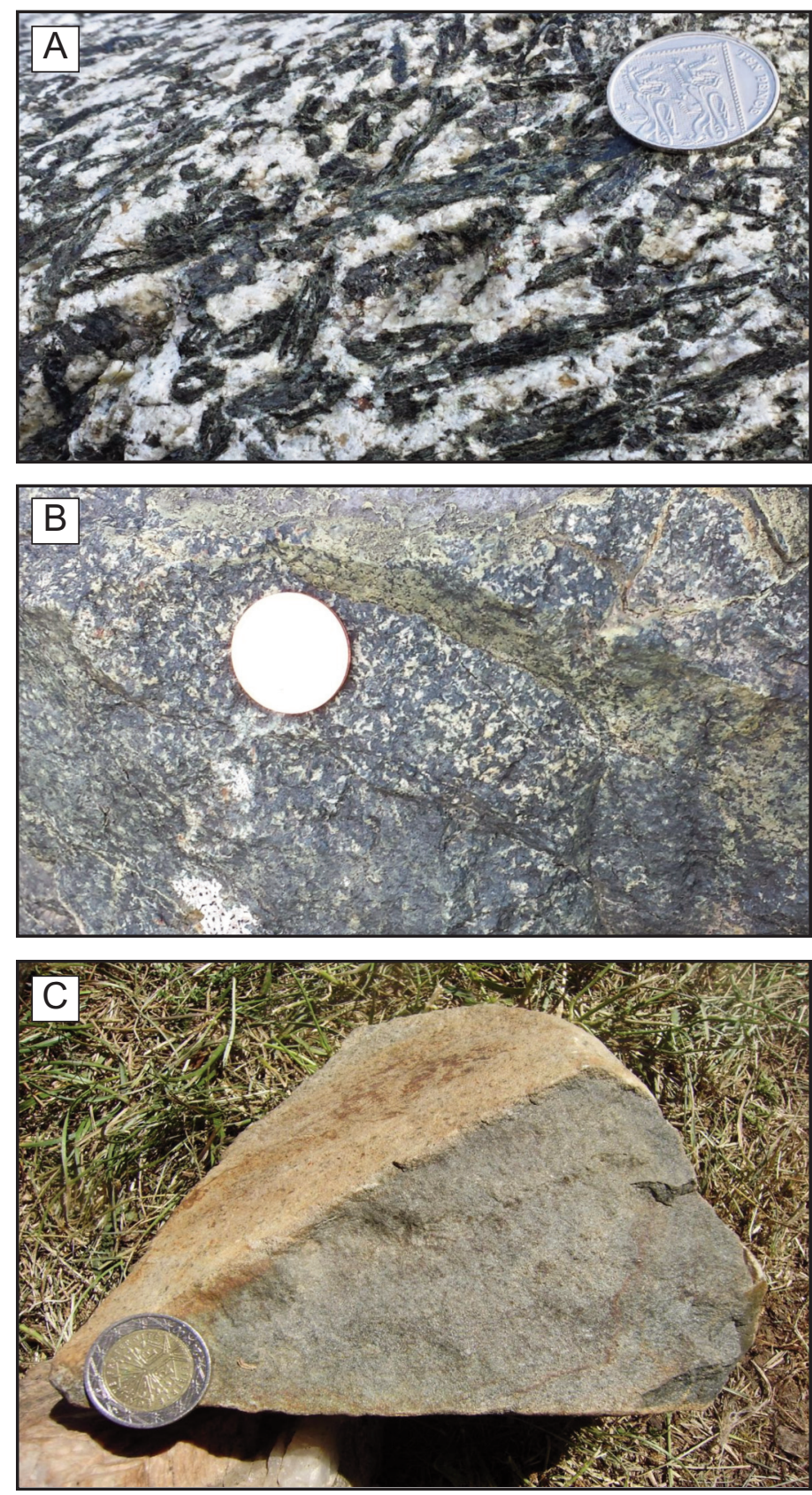

Figure 3. Field photographs of (a) mafic rock of the appinite suite with prismatic amphibole grains within a plagioclase matrix, (b) intermediate-felsic rock of the appinite suite with amphibole clumps within a plagioclase matrix, and (c) a lamprophyre dyke with fine-grained biotite and hornblende grains within a plagioclase-rich matrix.

geochronology laboratory at Queen's University in Kingston, Ontario, on amphibole separated from two representative samples (INK-004 and GLE-004). Electron microprobe analyses and X-ray images of representative hornblende from each sample are shown in the supplemental files SF-1 to SF-5. The amphibole analyses show variations from 39.7 to $42.7 \mathrm{wt} . \%$ in $\mathrm{SiO}_{2}, 11.8$ to 13.9 wt. $\%$ in $\mathrm{Al}_{2} \mathrm{O}_{3}, 10.8$ to 12.4 wt. $\%$ in $\mathrm{CaO}, 2.1$ to 4.03 wt. $\%$ in $\mathrm{TiO}_{2}$ and 0.59 to 1.24 wt. $\% \mathrm{~K}_{2} \mathrm{O}$. Mean $\mathrm{Ca} / \mathrm{K}$ ratios are between 11.1 and 13.3. Because the water and halogen contents of the amphiboles are unknown, the amphibole formulae are calculated to $23(\mathrm{O})$, and the $\mathrm{Fe}^{2+} / \mathrm{Fe}^{3+}$ ratio determined after the method described by Pe-Piper (1988). According to the classification of Leake et al. (2004), the amphiboles are calcic as they all have $(\mathrm{Ca}+\mathrm{Na})^{\mathrm{B}} \geq 1.00$ and $\mathrm{NaB}>0.50$ apfu (atoms per formula unit). The amphiboles typically have $\mathrm{Si}^{\mathrm{IV}}$ between 5.9 and 6.4, with $\mathrm{Al}^{\mathrm{IV}}$ from 2.1 to 1.6 and $\mathrm{Mg} /\left(\mathrm{Mg}+\mathrm{Fe}^{2+}\right)$ between 0.6 and 0.9. The analyses indicate that the amphibole compositions are typical of tschermakitic hornblende of igneous origin (Leake 1978; Leake et al. 2004).

The sample locations are shown on Figure 2 and listed in Table 1. Both samples were hand-crushed and single grains of hornblende cleavage fragments free of visible overgrowths were selected for analysis. Mineral separates and flux-monitors (standards) were wrapped in $\mathrm{Al}$ foil. The resulting disks were stacked vertically into an $8.5 \mathrm{~cm}$ long and $2.0 \mathrm{~cm}$ diameter $\mathrm{Al}$ irradiation capsule, and then irradiated with fast neutrons in position 8C of the McMaster Nuclear Reactor (Hamilton, Ontario) for a duration of $86.4 \mathrm{~h}$ (at $2.5 \mathrm{MWH}$ ). Packets of flux monitors were located at $\sim 0.5 \mathrm{~cm}$ intervals along the irradiation container and the J-value for each of the samples was determined by least-squares, second-order polynomial interpolation using weighted means of replicate analyses of splits of the bracketing monitors position in the capsule.

The samples were loaded into flat-bottomed pits in a copper sample-holder and placed beneath the $\mathrm{ZnS}$ view-port of a small, bakeable, stainless-steel chamber connected to an ultrahigh vacuum purification system. Following bake-out at $105^{\circ} \mathrm{C}$, a $30 \mathrm{~W}$ New Wave Research MIR 10-30 $\mathrm{CO}_{2}$ laser with a faceted lens was used to heat the samples for 3 minutes at increasing percent power settings ( $2 \%$ to $45 \%$; beam diameter $3 \mathrm{~mm}$ ). After purification using hot and cold SAES C50 getters (for 5 minutes), the evolved gas was admitted to an MAP 216 mass spectrometer, with a Bäur Signer source and an analogue electron multiplier (set to a gain of 100 over the Faraday detector).

Measured Ar isotope peak heights were extrapolated to zero-time and corrected for discrimination using an ${ }^{40} \mathrm{Ar} /{ }^{36} \mathrm{Ar}$ atmospheric ratio of 298.56 (Lee et al. 2006) and measured ratios of atmospheric Ar. Blanks, measured routinely, were subtracted from the subsequent sample gas fractions. The extraction blanks were typically $<10 \times 10^{-13},<0.5 \times 10^{-13},<0.5$ $\times 10^{-13}$, and $<0.5 \times 10^{-13} \mathrm{~cm}^{-3}$ STP for masses 40, 39, 37, and 36, respectively. ${ }^{39} \mathrm{Ar}$ and ${ }^{37} \mathrm{Ar}$ were corrected for radioactive decay during and after irradiation. Corrections were made for neutron-induced ${ }^{40} \mathrm{Ar}$ from potassium, ${ }^{39} \mathrm{Ar}$ and ${ }^{36} \mathrm{Ar}$ from calcium, and ${ }^{36} \mathrm{Ar}$ from chlorine (Roddick 1983; Onstott et al. 1991). Dates and errors were calculated using the procedure of Dalrymple et al. (1981) and the ${ }^{40} \mathrm{~K}$ decay constant of Min et al. $\left(2000 ; 5.463 \times 10^{-10} 1 / \mathrm{y}\right)$. Plateau and inverse isotope correlation dates were calculated using ISOPLOT v. 3.60 (Ludwig 2008). A plateau is herein defined as 3 or more contiguous steps containing $>50 \%$ of the ${ }^{39} \mathrm{Ar}$ released, with a probability of fit $>0.01$ and MSWD $<2$. If the contiguous steps contain $<50 \%$ of the ${ }^{39} \mathrm{Ar}$ released, it is referred to as a plateau segment.

Quoted errors represent the analytical precision at $2 \sigma$, assuming that the error in the age of the flux monitor is zero. 
Table 1. Lithology, location and analysis of samples selected for geochemical analysis from the Ardara appinite plutons and coeval lamprophyre dykes, Donegal, Ireland.

\begin{tabular}{|c|c|c|c|c|c|}
\hline Sample ID & Rock Type & Location & Northing & Easting & Analysis \\
\hline \multicolumn{6}{|c|}{ Appinite Suite } \\
\hline$A P P-008$ & Mafic Dyke & Ardara & 54.7538 & -8.3819 & REE \\
\hline APP-015 & Mafic Dyke & Dawros Head & 54.8333 & -8.4552 & REE \\
\hline$L B B-003$ & Mafic Dyke & Loughros Beg Bay & 54.7698 & -8.4816 & REE, Sm-Nd \\
\hline INK-004 & Mafic Dyke & Portnoo & 54.8475 & -8.4801 & $\mathrm{REE}, \mathrm{Sm}-\mathrm{Nd}, \mathrm{Ar}-\mathrm{Ar}$ \\
\hline$A G R-001$ & Mafic Dyke & Dawros Head & 54.7337 & -8.4332 & REE, Sm-Nd \\
\hline GLE-001 & Mafic Dyke & Glenties & 54.8223 & -8.277 & REE, Sm-Nd \\
\hline GLE-004 & Mafic Dyke & Glenties & 54.7477 & -8.2946 & $\mathrm{REE}, \mathrm{Sm}-\mathrm{Nd}, \mathrm{Ar}-\mathrm{Ar}$ \\
\hline ROS-004 & Mafic Dyke & Rossbeg & 54.8226 & -8.5296 & REE \\
\hline INK-007 & Felsic Dyke & Portnoo & 54.82575 & -8.5603 & REE \\
\hline INK-008 & Felsic Dyke & Portnoo & 54.84329 & -8.4717 & REE, Sm-Nd \\
\hline FEL-005 & Felsic Dyke & Dawros Head & 54.8254 & -8.5544 & $\mathrm{REE}, \mathrm{Sm}-\mathrm{Nd}$ \\
\hline DWH-007 & Felsic Dyke & Dawros Head & 54.8331 & -8.5502 & REE \\
\hline INK-005 & Felsic Dyke & Portnoo & 54.84436 & -8.4724 & REE \\
\hline DWH-006 & Intermediate & Dawros Head & 54.83297 & -8.5532 & REE \\
\hline INH-001 & Intermediate Dyke & Loughros Beg Bay & 54.82922 & -8.5108 & REE \\
\hline \multicolumn{6}{|c|}{ Lamprophyre Dykes } \\
\hline FEL-001 & Mafic Dyke & Dawros Head & 54.8254 & -8.5505 & REE, Sm-Nd \\
\hline LMB-009 & Mafic Dyke & Loughros More Bay & 54.8365 & -8.514 & REE, Sm-Nd \\
\hline LBB-002 & Mafic Dyke & Loughros Beg Bay & 54.77122 & -8.4833 & $\mathrm{REE}, \mathrm{Sm}-\mathrm{Nd}$ \\
\hline DMH-003 & Mafic Dyke & Dumore Head & 54.8365 & -8.5155 & $\mathrm{REE}, \mathrm{Sm}-\mathrm{Nd}$ \\
\hline DWH-003 & Mafic Dyke & Dawros Head & 54.8308 & -8.5548 & REE, Sm-Nd \\
\hline ROS-005 & Mafic Dyke & Rossbeg & 54.82322 & -8.529 & REE \\
\hline LMB-005 & Mafic Dyke & Loughros More Bay & 54.7870 & -8.5143 & REE \\
\hline
\end{tabular}

This precision is suitable for comparing within-spectrum variation and determining which steps form a plateau (e.g. McDougall and Harrison 1988, p. 89). The dates and J-values were referenced to GA1550 biotite (98.5 Ma; Spell and McDougall 2003; McDougall and Wellman 2011; recalculated relative to an FC sanidine age of $28.201 \mathrm{Ma}$; Kuiper et al. 2008).

\section{Results}

A summary of the ${ }^{40} \mathrm{Ar} /{ }^{39} \mathrm{Ar}$ data obtained is shown in supplemental file SF-6. Step heating of hornblende separates from these two samples resulted in release patterns with initially high ages, decreasing over the first few percent of the ${ }^{39} \mathrm{Ar}$ released, then increasing irregularly to robust well-defined plateaus. In this study, the ISOPLOT plateau dates represent the best estimate of the age of the samples. For both spectra, the plateau steps incorporate those with typical yield $\mathrm{Ca} / \mathrm{K}$ ratios (12 to 15) calculated from the ${ }^{37} \mathrm{Ar} /{ }^{39} \mathrm{Ar}$ ratios comparable to those obtained from the electron microprobe analyses (11 to 13).

Sample INK-004 is from an appinitic intrusion into Dalradian host rock taken near the Portnoo coast. This sample contains abundant amphibole, biotite clusters and interpenetrating apatite in a matrix dominated by plagioclase and amphibole. It yielded a ten-step plateau with $90.5 \%$ of the ${ }^{39} \mathrm{Ar}$ released and a plateau date of $434.8 \pm 1.2 \mathrm{Ma}$ (Fig. $4 \mathrm{a}$ ), and within error a concordant inverse isochron date of $434.2 \pm 2.1 \mathrm{Ma}$ (Fig. 4b). The inverse isochron included 12 of the 14 steps, $94.3 \%$ of the
${ }^{39} \mathrm{Ar}$ released, had a slightly non-atmospheric initial ${ }^{40} \mathrm{Ar} /{ }^{36} \mathrm{Ar}$ ratio $(333 \pm 18)$ and an MSWD $=0.63$. The ages are essentially the same at each step except for those produced by the argon released $(5 \%-10 \%)$ during the initial heating. During the first few steps, traces of loosely bound excess Ar caused the older dates in this part of the spectrum.

Sample GLE-004 is from an appinitic intrusion at Glenties in the contact aureole of the Ardara pluton $\sim 200 \mathrm{~m}$ from the exposed contact. This sample is dominated by phenocrysts of olivine, amphibole and augite in a groundmass composed of phlogopite, biotite, plagioclase and orthoclase. The sample yielded a seven-step high-temperature plateau with a date of $440.1 \pm 1.4 \mathrm{Ma}$ (65.8\% of the ${ }^{39} \mathrm{Ar}$ released) (Fig.5a). Because the inverse isochron ratios for the high-temperature steps were tightly clustered, a reliable ISOPLOT Model 1 solution could not be obtained. A Model 2 solution using all points yielded a date of $433.7 \pm 5.5 \mathrm{Ma}$ (Fig 5b) and an initial ${ }^{40} \mathrm{Ar} /{ }^{36} \mathrm{Ar}$ ratio of $405 \pm 14$. The initial ratio is well above that for atmospheric argon and suggests that excess Ar was incorporated in the hornblende. As in Sample INK-004, the ages are essentially the same at each step except for those produced by the argon released $(5 \%-30 \%)$ during the initial heating. During the first few heating steps, likely traces of excess Ar caused the ages to appear about 50-80 million years older.

\section{Interpretation}

The Ar closure temperature for hornblende is variable and 

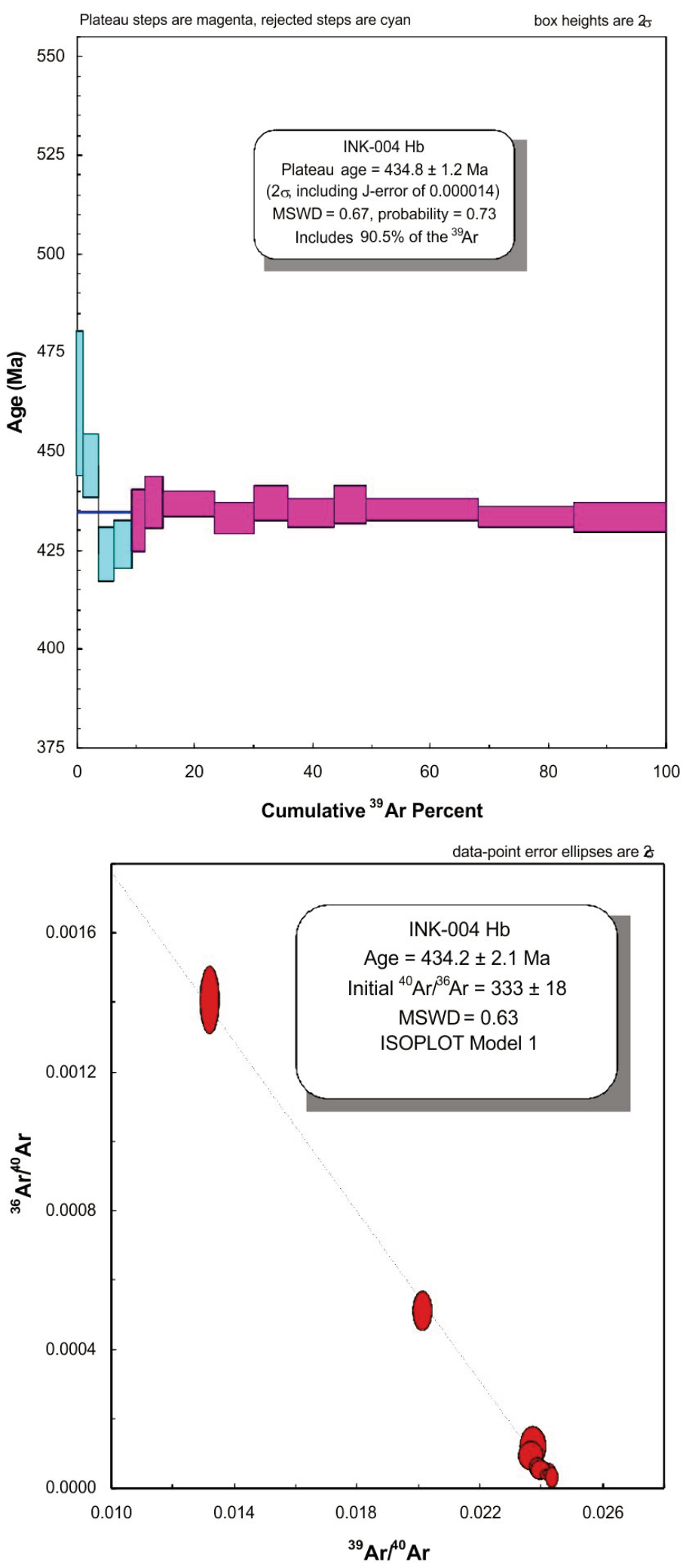

Figure 4. (a) ${ }^{40} \mathrm{Ar} /{ }^{39} \mathrm{Ar}$ age spectrum and (b) ${ }^{40} \mathrm{Ar} /{ }^{39} \mathrm{Ar}$ inverse isochron plot for sample INK-004.

depends on several compositional factors. Because the dated amphibole samples have $\mathrm{Mg} /(\mathrm{Mg}+\mathrm{Fe})$ ratios in the range of the hornblende investigated by Harrison (1982; 0.6-0.8), it is
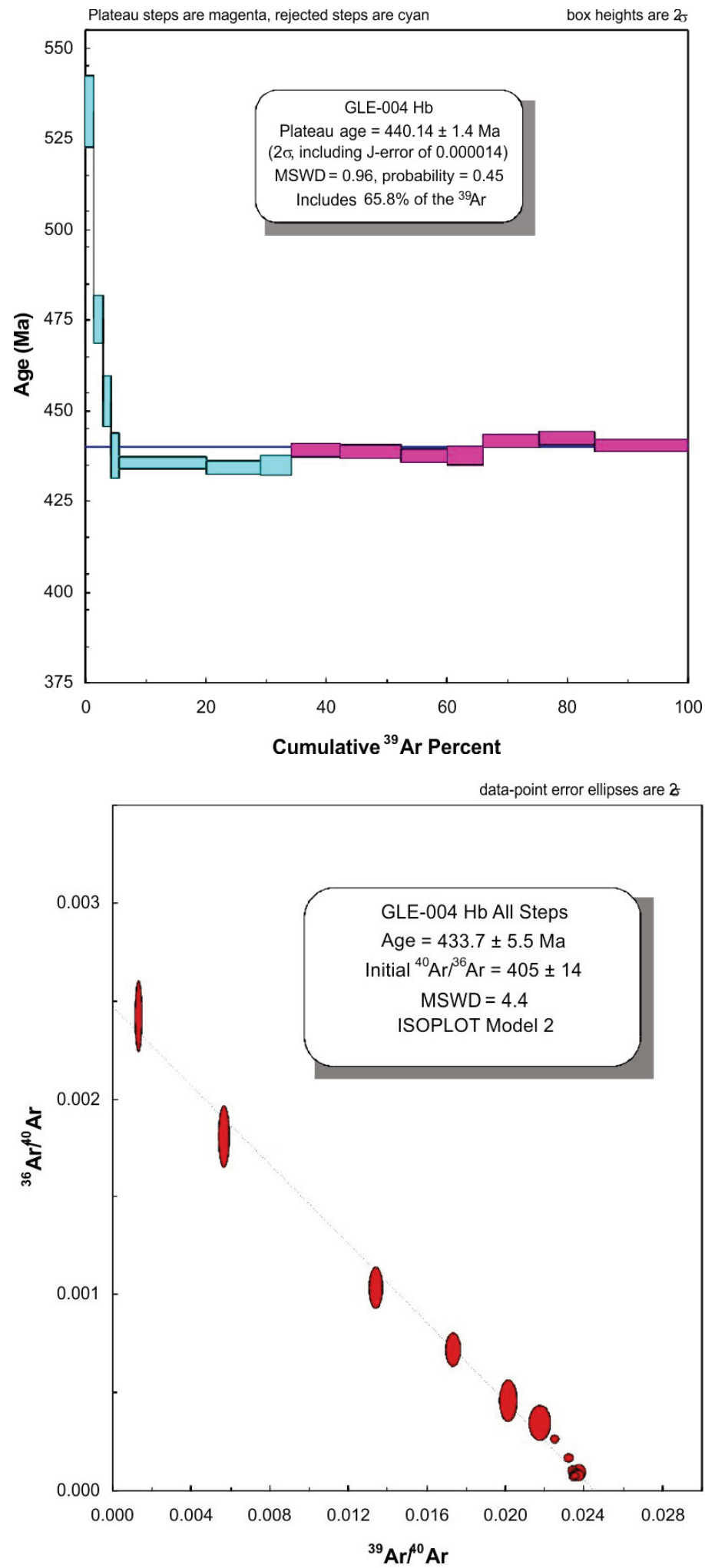

Figure 5. (a) ${ }^{40} \mathrm{Ar} /{ }^{39} \mathrm{Ar}$ age spectrum and (b) ${ }^{40} \mathrm{Ar} /{ }^{30} \mathrm{Ar}$ inverse isochron plot for sample GLE-004.

appropriate to calculate a closure temperature based on his experimental diffusion parameters. The relatively small size of both intrusions together with their mid-crustal level of 
emplacement, suggests that cooling through the Ar closing temperature for hornblende was rapid. Using Dodson's (1973) iterative expression for closure temperature and a conservative cooling rate of $100^{\circ} \mathrm{C} / \mathrm{m} . \mathrm{y}$. a probable minimum closure temperature of $545^{\circ} \mathrm{C}$ is obtained. Sample location INK-004 is $2 \mathrm{~km}$ from the contact of the Ardara pluton and is not likely to have experienced any reheating from the Ardara pluton. GLE-004 is within $\sim 500 \mathrm{~m}$ of the southern contact of the Ardara and may have been reheated. However, based on geothermometry and geobarometry in pelitic rocks, Kerrick (1987) modelled the thermal gradient across the aureole. Based on his contact temperature profile and pressures of $2-3 \mathrm{kbar}$, it is unlikely that GLE-004 would have been re-heated to a temperature $>500^{\circ} \mathrm{C}$. The calculated closure temperature is significantly higher than the metamorphic temperatures experienced by the Dalradian metasedimentary rocks that host the Ardara appinite suite, which are at regional greenschist facies. The cooling age of $434.2 \pm 2.1 \mathrm{Ma}(2 \sigma)$ obtained from the ${ }^{40} \mathrm{Ar} /{ }^{39} \mathrm{Ar}$ inverse isochron is consequently interpreted to have been acquired during rapid cooling of the appinitic magma. Given the relatively small size and mid-crustal levels of emplacement, both of which would suggest rapid cooling through the Ar closing temperature for hornblende, the ages are considered to date igneous emplacement closely. These data therefore indicate a Silurian (late Llandovery-early Wenlock) crystallization age for the Ardara appinite suite and, when combined with field relationships, suggest that emplacement of the suite slightly preceded emplacement of the earliest Donegal granite plutons, including the Ardara pluton (Fowler and Henney 1996; Atherton and Ghani 2002; Condon et al. 2004).

\section{GEOCHEMISTRY}

Twenty-two samples representative of the appinite suite and lamprophyre dykes were collected from all the larger appinitic bodies and several lamprophyre dykes surrounding the Ardara pluton. These were sent to the Bureau Veritas Commodities Canada, Ltd., Vancouver, British Columbia, for major and trace element analysis by X-ray fluorescence (XRF) using a Philips PW2400 X-ray spectrometer. The samples were obtained from fine- to coarse-grained appinitic intrusions and lamprophyre dykes intruding Dalradian host rock at Dunmore Head, Portnoo, Rossbeg, Loughros More Bay, Loughros Beg Bay and Ardara (Fig. 2). Sample locations are given in Table 1 and shown on Figure 2. Rare earth and selected trace elements were analyzed by Inductively Coupled Plasma Mass Spectrometry (ICP-MS), also at the Bureau Veritas Commodities Canada, Ltd., using a Fisons/Applied Research Laboratories 8420+ wavelength dispersive $\mathrm{X}$-ray spectrometer. A subset of the powdered samples was additionally analyzed for $\mathrm{Sm}-\mathrm{Nd}$ isotopic values at Memorial University using thermal ionization mass spectrometry.

\section{Whole-rock Analysis}

Samples of the appinite suite were taken from mafic enclaves within the Ardara pluton and from dykes up to $5 \mathrm{~m}$ in width that cut the Dalradian host rocks. Selected major and trace ele- ment data for these samples are given in supplementary file SF-7. Loss-on-ignition (LOI) values are variable, ranging from 1.9 to $2.9 \mathrm{wt} . \%$ in mafic rocks and 1.1 to $2.6 \mathrm{wt} . \%$ in intermediate-felsic rocks of the appinite suite, and from 49.5 to 57.2 wt. $\%$ in the lamprophyre dykes.

\section{Appinite Suite}

Mafic rocks of the appinite suite have $\mathrm{SiO}_{2}$ content ranging from 45.8-53.3 wt. $\%, \mathrm{MgO}$ values from 5-16 wt. $\%$, magnesium numbers $(\mathrm{Mg} \#),\left(100 \times \mathrm{MgO} /\left(\mathrm{MgO}+0.9 \mathrm{FeO}_{\text {tot }}\right)\right.$ that range from 22 to 57 and variable $\mathrm{Al}_{2} \mathrm{O}_{3}$ contents (13.0-22.0 wt. \%). Intermediate-felsic members of the suite have higher $\mathrm{SiO}_{2}$ concentrations $(64.8-72.1 \mathrm{wt} . \%)$ but a similar range in $\mathrm{Al}_{2} \mathrm{O}_{3}(13.3-19.1$ wt. \%) and much lower $\mathrm{MgO}$ values $(0.28$ 0.78 wt. $\%)$.

Petrographic evidence for alteration in rocks of the appinite suites necessitates the emphasis on concentrations of less mobile high-field strength elements (HFSE) and rare earth elements (REE) instead of the more mobile large ion lithophile elements (LILE) in the interpretation of petrogenesis and tectonic setting (e.g. Winchester and Floyd 1977). The mobility of alkalis $\left(\mathrm{Na}_{2} \mathrm{O}, \mathrm{K}_{2} \mathrm{O}\right)$ is evident from their scatter on Harker variation diagrams (Fig. 6). The $\mathrm{Zr} / \mathrm{Ti}$ vs $\mathrm{Nb} / \mathrm{Y}$ diagram (Pearce 1996) is used to replace the total alkali-silica diagram because $\mathrm{Zr} / \mathrm{Ti}$ and $\mathrm{Nb} / \mathrm{Y}$ are respective proxies for the silica and alkali contents (Fig. 7). The mafic rocks of the suite are sub-alkalic and plot in the basaltic andesite to basalt fields. On $\mathrm{FeO}_{\text {tot }} / \mathrm{MgO}$ vs $\mathrm{FeO}$ and $\mathrm{FeO}_{\text {tot }} / \mathrm{MgO}$ vs $\mathrm{SiO}_{2}$ (Miyashiro 1974) discrimination diagrams (Fig. 8a,b), the mafic rocks show a limited range in $\mathrm{SiO}_{2}$ over a large range in $\mathrm{FeO}_{\text {tot }} / \mathrm{MgO}$, a feature that is typical of a tholeiitic differentiation trend, but the low $\mathrm{FeO}_{\text {tot }} / \mathrm{MgO}$ ratio exhibited by several mafic samples is typical of calc-alkaline suites.

The mafic rocks are also characterized by generally high $\mathrm{MgO}$ (4.1 to 16.7 wt.\%), $\mathrm{Cr}_{2} \mathrm{O}_{3}$ (0.01 to 0.06 wt.\%), Ni (98-288 ppm), Ba (233-528 ppm), and V (179-462 ppm) abundances as well as elevated LILE- and light rare-earth elements (LREE), and slightly depleted heavy rare-earth elements (HREE). The high concentrations of $\mathrm{Mg}, \mathrm{Ni}, \mathrm{Cr}$ and $\mathrm{Ba}$ are indicative of a mantle source (Atherton and Ghani 2002). On chondrite-normalized REE diagrams, the mafic rocks display a moderate negative Eu anomaly indicating fractionation of plagioclase (Fig. 9a). On multi-element plots (Pearce 1983), the rocks also display moderately negative anomalies in HFS elements such as $\mathrm{Nb}, \mathrm{P}, \mathrm{Zr}$ and Ti (Fig. 10a,b). The overall slope, a general source enrichment of LILE (Fig. 9b), and the negative anomalies in HFS elements are characteristic of a mantle source in a subduction zone setting. The mafic rocks additionally have generally high $\mathrm{Zr} / \mathrm{Y}$, a characteristic typical of within-plate tholeiitic basalt. In the Ti/1000 vs V diagram (Fig. 11), the mafic rocks plot in the fields of mid-ocean ridge (MORB) and back-arc basin (BAB) basalt.

$\mathrm{On} \mathrm{Th} / \mathrm{Yb}$ and $\mathrm{Ce} / \mathrm{Yb}$ vs $\mathrm{Ta} / \mathrm{Yb}$ plots (Fig. 12a,b), the vertical axis detects subduction components so that rocks formed in a coeval arc environment, or those contaminated by continental crust plot above typical mantle values. The rocks of the appinite suite display calc-alkalic to shoshonitic compositions 

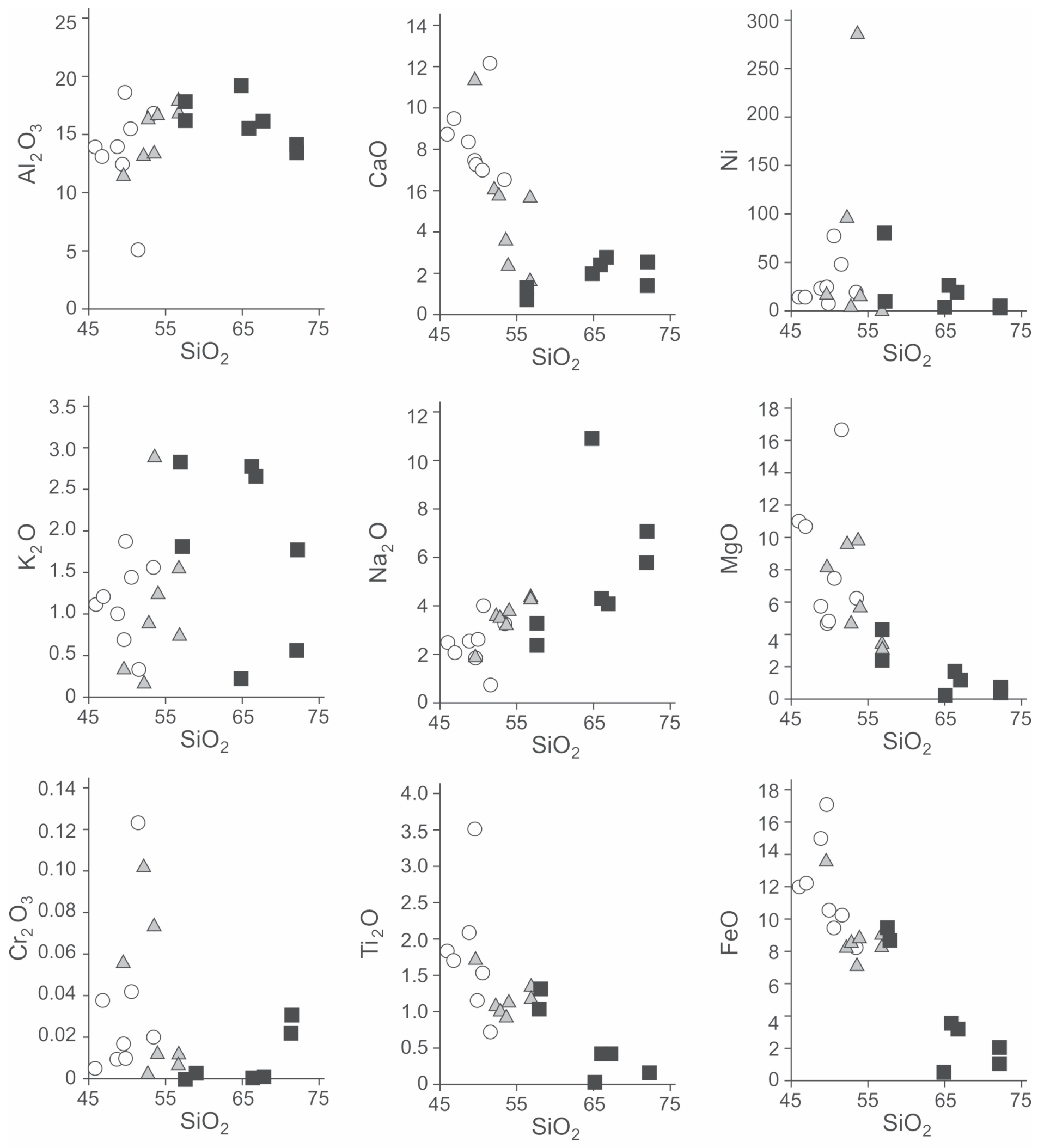

$\begin{array}{lll}\text { Appinite suite } & \bigcirc \text { mafic } \\ & \text { felsic }\end{array}$ Lamprophyre dykes $\triangle$

Figure 6. Harker diagrams for major element oxides for the Donegal appinite suite. 


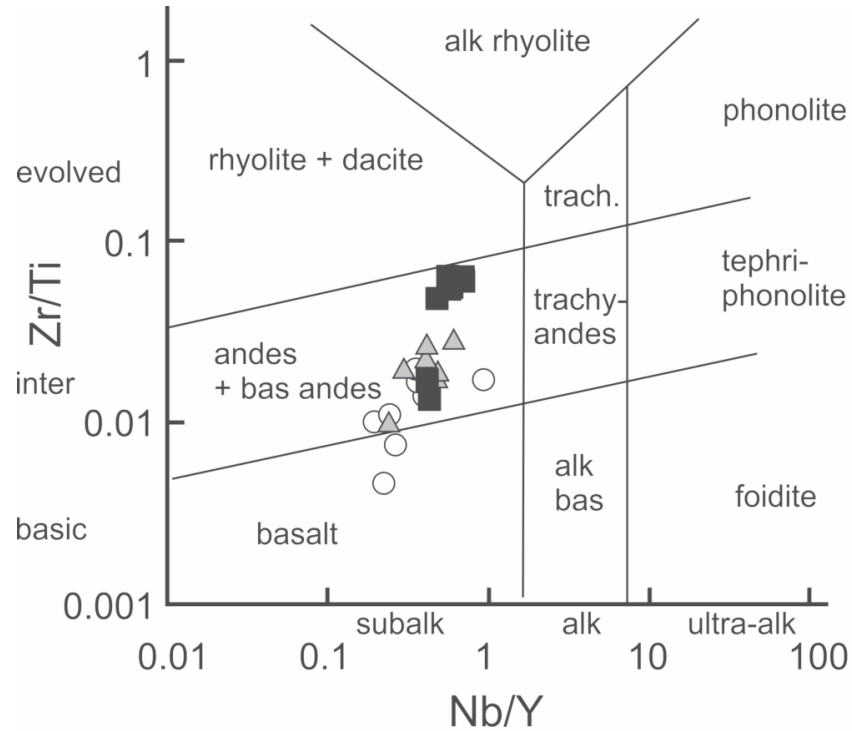

Appinite suite $\quad \begin{aligned} & \text { mafic } \\ & \text { felsic }\end{aligned}$ Lamprophyre dykes $\triangle$

Figure 7. $\mathrm{Zr} / \mathrm{Ti}$ vs $\mathrm{Nb} / \mathrm{Y}$ diagram for classifying the Donegal appinites (Pearce 1996 after Winchester and Floyd 1977).

on these plots. On the $\mathrm{La} / \mathrm{Yb}$ vs $\mathrm{Th} / \mathrm{Yb}$ plot (Fig. 13), the mafic and intermediate-felsic rocks of the appinite suite display island arc to continental margin arc characteristics. As arc magmas are enriched in Th and depleted in Ta, they plot nearer the Hf-Th join compared to MORB or within-plate basalts on the Hf-Th-Ta diagram (Fig. 14). The rocks of the appinite suite plot as calc-alkaline basalt and have higher Th than typical island arc tholeiite (IAT), plotting closer to the Th apex of this discrimination diagram.

\section{Lamprophyre Dykes}

The lamprophyre dykes are mafic to intermediate and range from 49.5 to 56.7 wt. $\%$ in $\mathrm{SiO}_{2}, 11.5$ to $18.0 \mathrm{wt} . \%$ in $\mathrm{Al}_{2} \mathrm{O}_{3}$, and 1.9 to 4.4 wt. $\%$ in $\mathrm{Na}_{2} \mathrm{O}$. These rocks are also high in $\mathrm{TiO}_{2}$, $\mathrm{MnO}, \mathrm{P}_{2} \mathrm{O}_{5}$ and $\mathrm{Cr}_{2} \mathrm{O}_{3}$.

Using the $\mathrm{FeO}_{\text {tot }} / \mathrm{MgO}$ vs $\mathrm{SiO}_{2}$ and $\mathrm{FeO}_{\text {tot }} / \mathrm{MgO}$ vs $\mathrm{FeO}$ (Miyashiro 1974; Arculus 2003) diagrams, the lamprophyre dykes display small ranges in $\mathrm{SiO}_{2}$ and $\mathrm{FeO}$ contents over a large range in $\mathrm{FeO}_{\text {tot }} / \mathrm{MgO}$ (Fig. 8a,b). The slope evident in this figure is typical of a tholeiitic differentiation trend.

The lamprophyre dykes are moderately enriched in the LREE and LILE relative to HREE. They display a moderate negative $\mathrm{Eu}$ anomaly indicating fractionation of plagioclase (Fig. 9c). In the Pearce (1983) multi-element plot, the samples display moderate negative anomalies in HFS elements such as $\mathrm{Nb}, \mathrm{P}, \mathrm{Zr}$ and Ti (Fig. 10c), which is characteristic of a subduction zone setting. All the lamprophyre dykes have high $\mathrm{Zr} / \mathrm{Y}$ (4.0 to 9.0$)$ and low Nb/Y (0.2 to 0.9), which is typical of within-plate tholeiitic basalt (Fig. 15a,b). In the Ti/1000 vs $\mathrm{V}$ diagram (Fig. 11), the lamprophyre dykes are characterized as MORB rocks.

On the Th/Yb and Ce/Yb vs Ta/Yb plots (Fig. 12a,b), the lamprophyre dykes plot as calc-alkaline to shoshonitic. On the $\mathrm{La} / \mathrm{Yb}$ vs $\mathrm{Th} / \mathrm{Yb}$ diagram (Fig. 13) they plot as continental
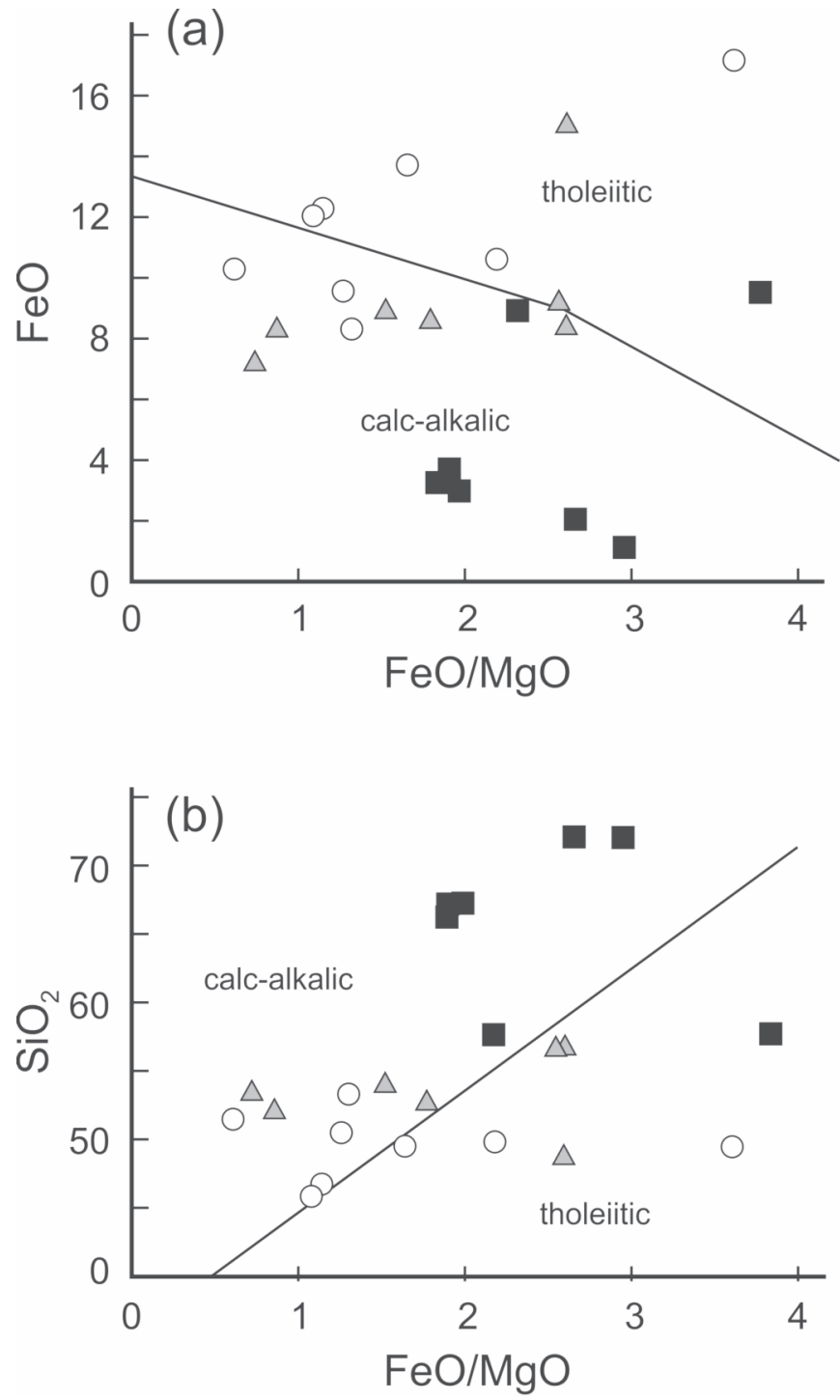

Figure 8. (a) $\mathrm{FeO}$ vs $\mathrm{FeO}_{\text {tot }} / \mathrm{MgO}$ and (b) $\mathrm{SiO}_{2}$ vs $\mathrm{FeO}_{\text {tot }} / \mathrm{MgO}$ for the mafic and felsic rocks of the appinite suite in Donegal (dividing lines after Miyashiro 1974). Symbols as in Figure 7.

margin arc rocks, whereas on the Hf-Th-Ta discrimination diagram (Fig. 14), they plot as calc-alkaline basalt and have higher Th than typical island arc tholeiites (IAT), plotting close to the Th apex.

\section{Sm-Nd Isotopic Analysis}

$\mathrm{Sm}-\mathrm{Nd}$ isotopic data for the Ardara appinite suite and lamprophyre dykes are summarized in Table 2 . Nd data are calculated at $t=435 \mathrm{Ma}$, based on the ${ }^{40} \mathrm{Ar} /{ }^{39} \mathrm{Ar}$ hornblende age determined for the suite. Sm and Nd values for rocks of the appinite suite and lamprophyre dykes lie in the ranges 1.99-6.86 $\mathrm{ppm}$ and $8.59-35.84 \mathrm{ppm}$, respectively. ${ }^{147} \mathrm{Sm} /{ }^{144} \mathrm{Nd}$ values range from 0.1071 to 0.1536 and ${ }^{143} \mathrm{Nd} /{ }^{144} \mathrm{Nd}$ values range from 0.512212 to 0.512490 . Depleted mantle model ages $\left(\mathrm{T}_{\mathrm{DM}}\right)$ were calculated according to DePaolo $(1981,1988)$. $\varepsilon N d t$ values $(t=435 \mathrm{Ma})$ for the appinite suite range from -4.8 to +3.1 and $\mathrm{T}_{\mathrm{DM}}$ values range from $805 \mathrm{Ma}$ to $1710 \mathrm{Ma}$ (Fig. 16). 

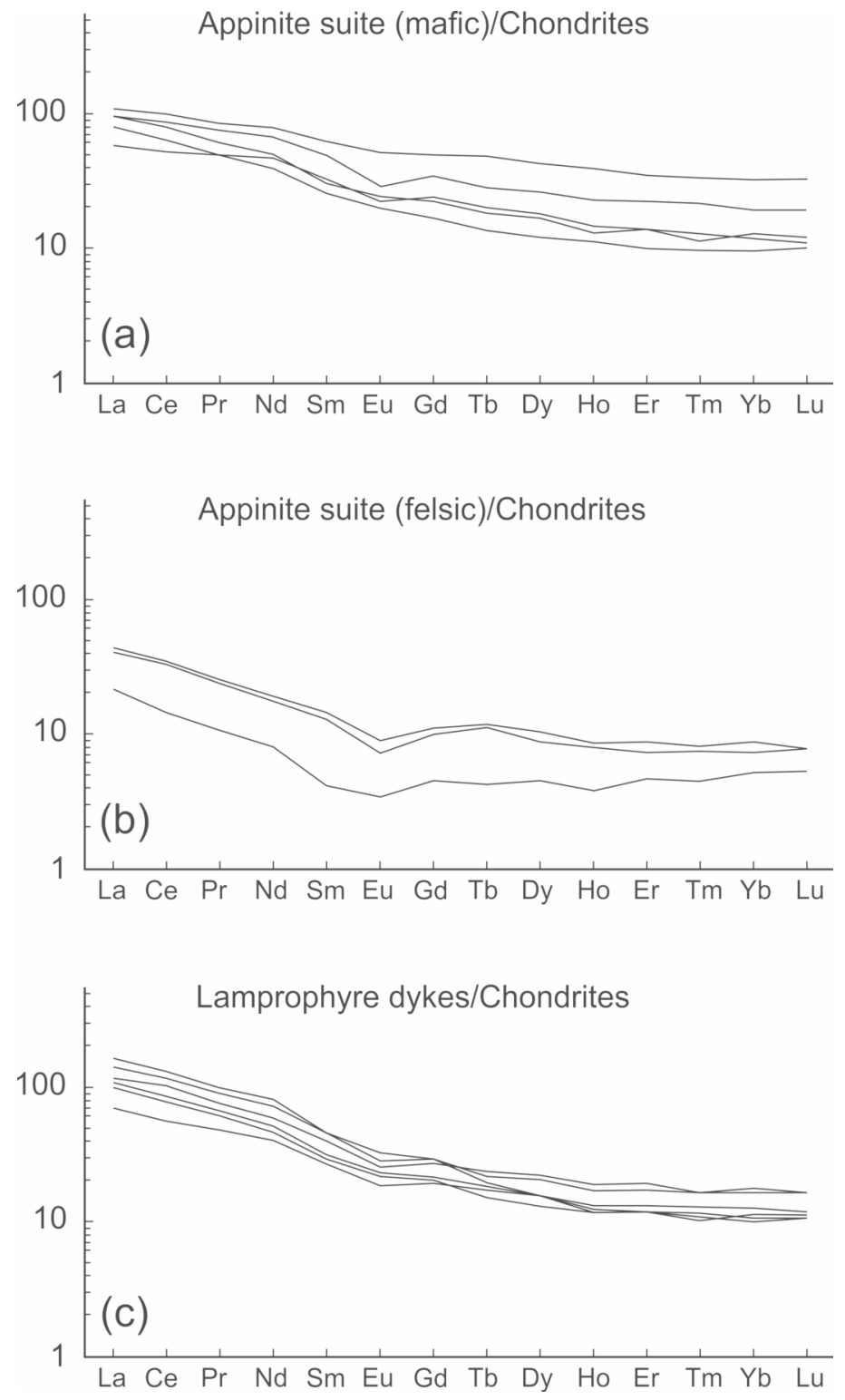

Figure 9. REE plots for representative samples of (a) mafic rocks of the appinite suite, (b) felsic rocks of the appinite suite and (c) the coeval lamprophyre dykes in Donegal (normalizing values from Sun and McDonough 1989).

\section{DISCUSSION}

The ${ }^{40} \mathrm{Ar} /{ }^{39} \mathrm{Ar}$ isotopic data closely constrain the timing of emplacement of the appinite suite. Given that the Ar closure temperature for hornblende is ca. $550^{\circ} \mathrm{C}$ (Harrison 1982) and that the host Dalradian metasedimentary rocks are at greenschist facies, the cooling ages obtained are interpreted to closely date igneous emplacement at ca. 434 Ma providing supporting evidence for the interpretation that the rocks of the appinite suite slightly predate the emplacement of the Ardara granite, and significantly predate the intrusion of the Main Donegal Granite. This conclusion is similar to that interpreted for the association of granite with appinite and lamprophyre in the Scottish Caledonides (Rogers and Dunning 1991; Fowler and Henney 1996; Atherton and Ghani 2002; Neilson et al. 2009). In the latter case, slab break-off is thought to have induced
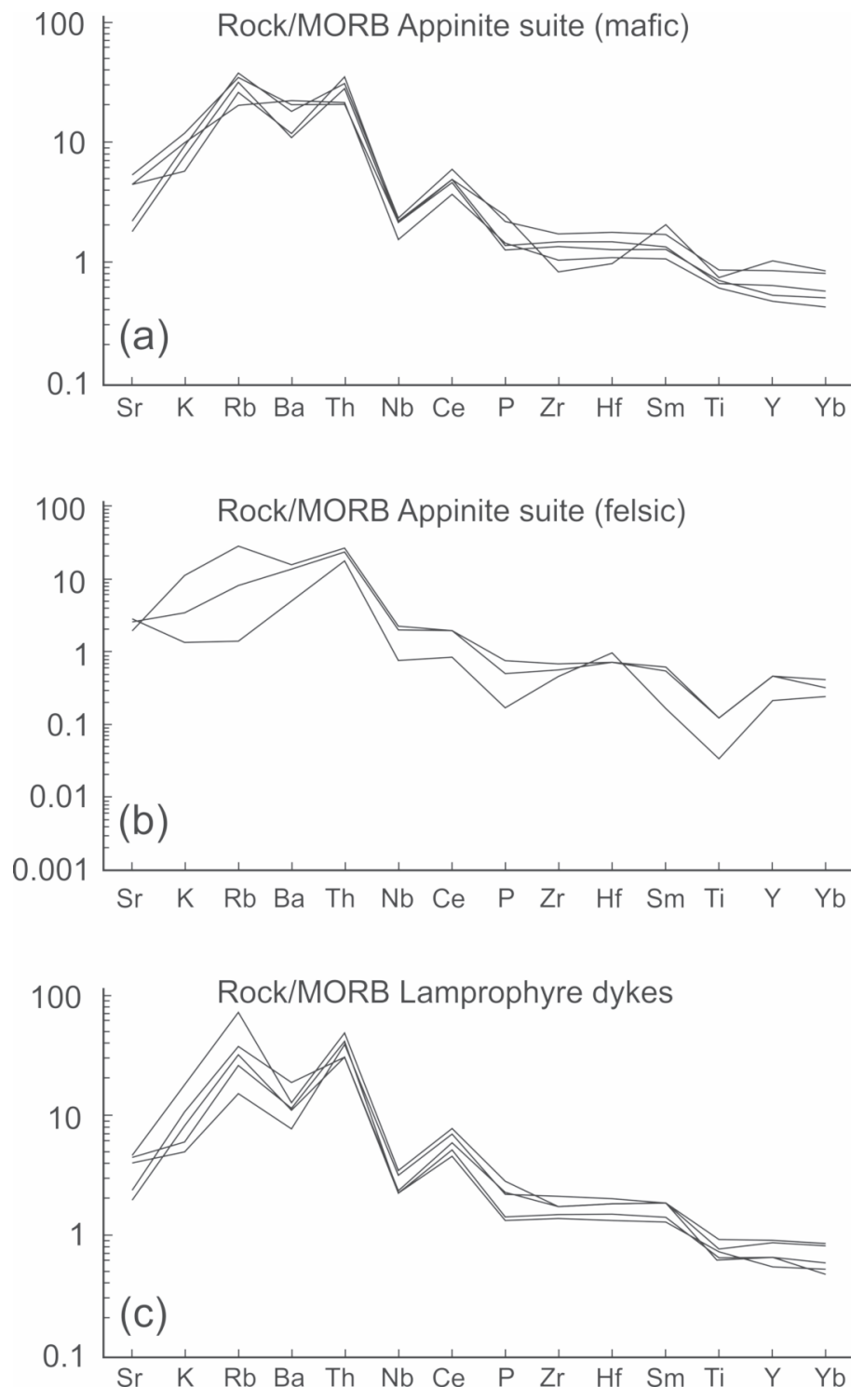

Figure 10. Multi-element plot for representative samples of (a) mafic rocks of the appinite suite, (b) felsic rocks of the appinite suite, and (c) the lamprophyre dykes in Donegal (normalizing values from Pearce 1983).

asthenospheric upwelling, which induced melting of the lithospheric mantle producing an appinitic mafic layer that underplated the crust (Fig. 17). Heat from underplated mafic crust is inferred to have initiated the production of crustal melts and voluminous granitoid magmatism (e.g. Neilson et al. 2009). The granitoid bodies, in turn, may have been produced by fractional crystallization of appinitic parent magmas (von Blackenburg and Davies 1995; Fowler et al. 2008).

The appinite suite and lamprophyre dykes around the Ardara pluton display similar chemical trends that, together with their field relationships, suggest they are comagmatic. For example, $\mathrm{Al}_{2} \mathrm{O}_{3}$ varies inversely and displays a systematic correlation with $\mathrm{SiO}_{2}$, and both rock groups show (i) negative correlations of $\mathrm{SiO}_{2}$ with $\mathrm{CaO}, \mathrm{MgO}, \mathrm{Fe}_{2} \mathrm{O}_{3}, \mathrm{TiO}_{2}, \mathrm{~V}, \mathrm{Cr}$ and $\mathrm{Ni}$, and positive correlations of $\mathrm{SiO}_{2}$ with $\mathrm{K}_{2} \mathrm{O}$ and $\mathrm{Na}_{2} \mathrm{O}$, (ii) plot in the andesite to basaltic andesite fields on the $\mathrm{Zr} / \mathrm{Ti}$ vs 


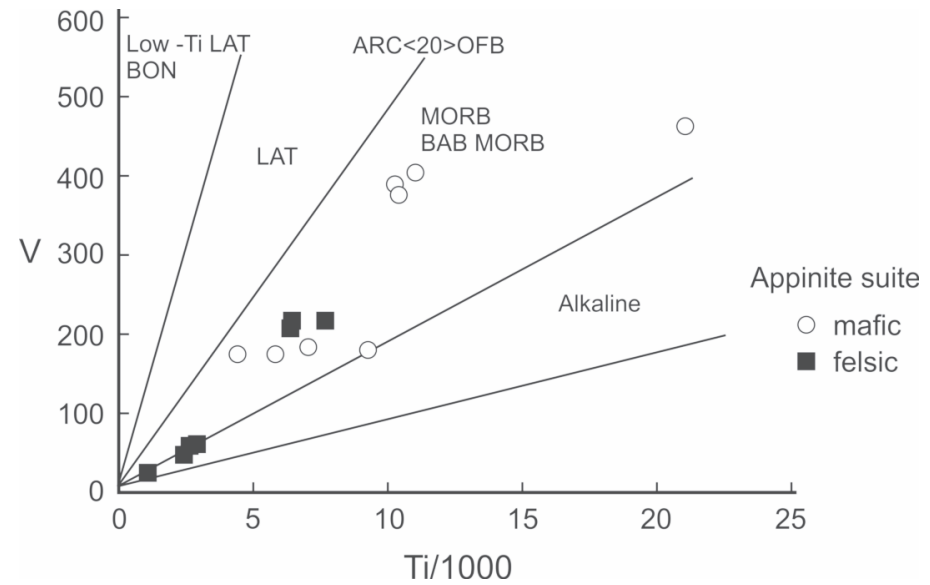

Figure 11. Ti/1000 vs V discrimination diagram for the appinite suite rocks in Donegal (after Shervais 1982). IAT (island arc tholeiite); BON (boninitic basalt); BAB (back-arc basin basalt).

$\mathrm{Nb} / \mathrm{Y}$ diagrams, and (iii) display very similar trends in REE plots, with elevated LREE and depleted HREE values. The same can be said for both groups of rocks on multi-element plots. Both groups additionally display negative anomalies in $\mathrm{Nb}, \mathrm{P}, \mathrm{Zr}$ and $\mathrm{Ti}$, which are characteristics of a mantle source in subduction zone settings. This interpretation is supported by a $437 \pm 5 \mathrm{Ma}$ crystallization age of a lamprophyre dyke to the east of the Leannan Fault in Donegal (Kirkland et al. 2013).

The appinite suite and lamprophyre dykes are also characterized by generally high $\mathrm{Mg}, \mathrm{Ni}, \mathrm{Cr}, \mathrm{Ba}$ and $\mathrm{V}$ values (typical of mafic rocks), coupled with elevated LILE, and are moderately enriched in LREE with flat HREE profiles, indicating they were generated from partial melting of sub-continental lithospheric mantle. Both also show negative $\mathrm{Nb}$ and $\mathrm{Ti}$ anomalies, indicating either crustal contamination of the magmas or modification of the original mantle source by subduction zone fluids (e.g. Pearce 1996). If these anomalies were a result of crustal contamination, however, they should also be reflected in the $\mathrm{Sm}-\mathrm{Nd}$ signature, resulting in a negative correlation between $\varepsilon \mathrm{Nd}$ and parameters such as $\mathrm{Ce} / \mathrm{Yb}$ and $\mathrm{Th} / \mathrm{Yb}$. As no such correlation is present (Fig. 18), the trace element contamination presumably occurred at the time of magma generation and so did not affect the isotopic system. Hence, the negative trace element anomalies probably reflect the composition of the metasomatized mantle source, implying that the low $\varepsilon N d t$ values of the appinite suite and lamprophyre dykes directly reflect the composition of the mantle from which they were derived. But while the low $\varepsilon N d t$ values are consistent with derivation from the sub-continental lithospheric mantle, the range of $\varepsilon N d t$ values suggest the additional involvement of a juvenile source.

Rocks of the appinite suite have been described from other orogenic belts of widely ranging age (e.g. Salmon 1998; Castro et al. 2002; Ye et al. 2008; Murphy 2013). Many are associated with major strike-slip faults (e.g. Murphy and Hynes 1990; Murphy 2013) including the appinite suite of Donegal (e.g. Hutton 1982; Hutton and Alsop 1996; Kirkland et al. 2008). In this scenario, the Ar-Ar ages probably reflect the timing of
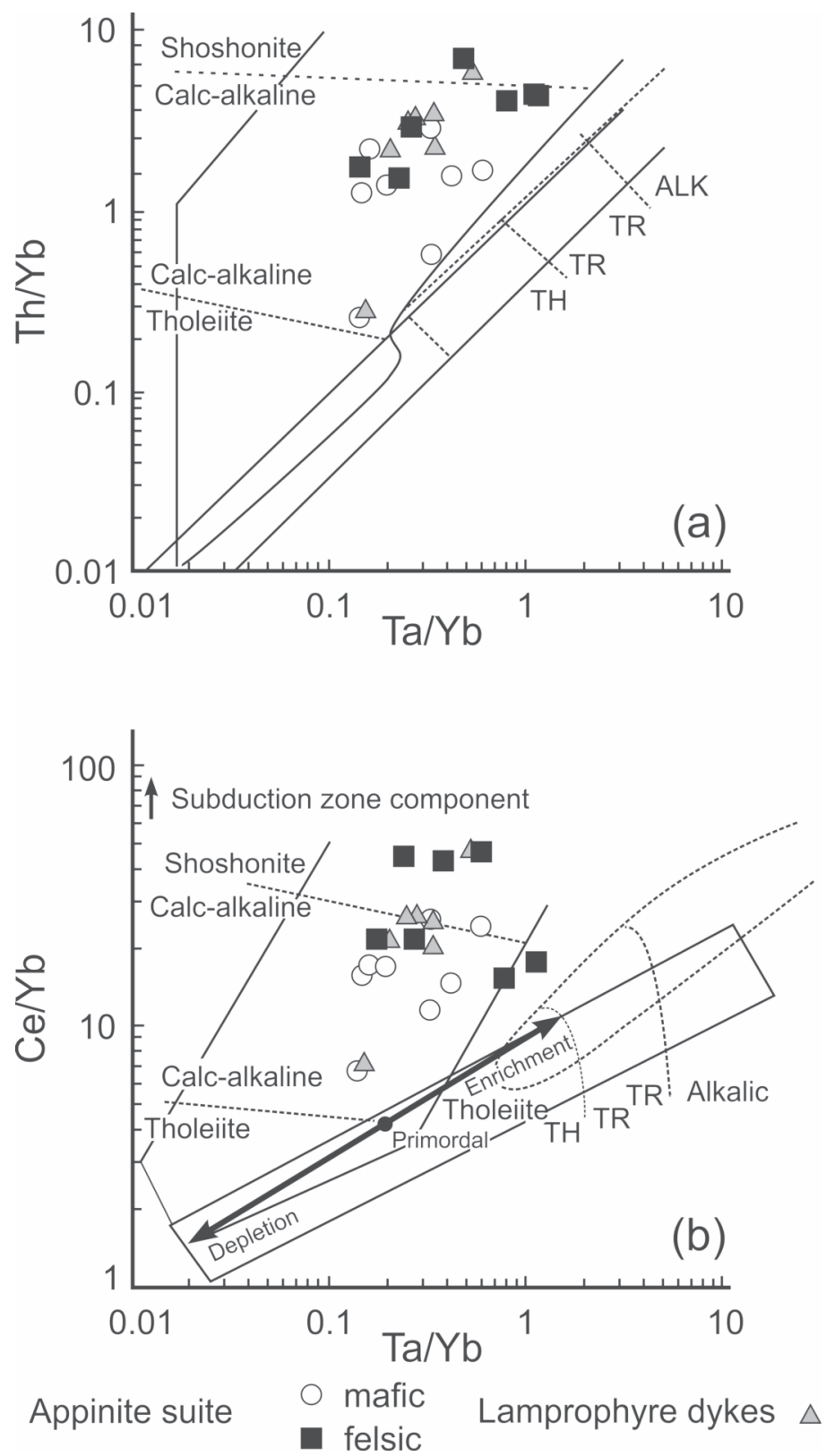

Figure 12. Log-log plots of (a) $\mathrm{Th} / \mathrm{Yb}$ vs $\mathrm{Ta} / \mathrm{Yb}$ and (b) $\mathrm{Ce} / \mathrm{Yb}$ vs $\mathrm{Ta} / \mathrm{Yb}$ (after Pearce 1982). TH (tholeiitic basalt); ALK (alkali basalt); TR (transition between tholeiitic and alkali basalt) for appinite suite rocks in Donegal.

emplacement of appinitic magma into relatively shallow crustal levels along active strike-slip faults, rather than the duration of appinitic magmatism. Potential sources of the appinitic and lamprophyric magmas include melting of the sub-continental lithospheric mantle (SCLM), melting of individual metasomatic veins within the mantle (Mitchell 1995), and/or melting of metasomatized underplated mafic crust. Only limited fractionation occurred during magma ascent and the magma was chemically modified by (i) the addition of upper crustal material, or (ii) the addition of fluids derived from this upper crustal material.

Regional constraints indicate appinitic and lamprophyric magmatism was coeval with (or shortly followed) collision, for 


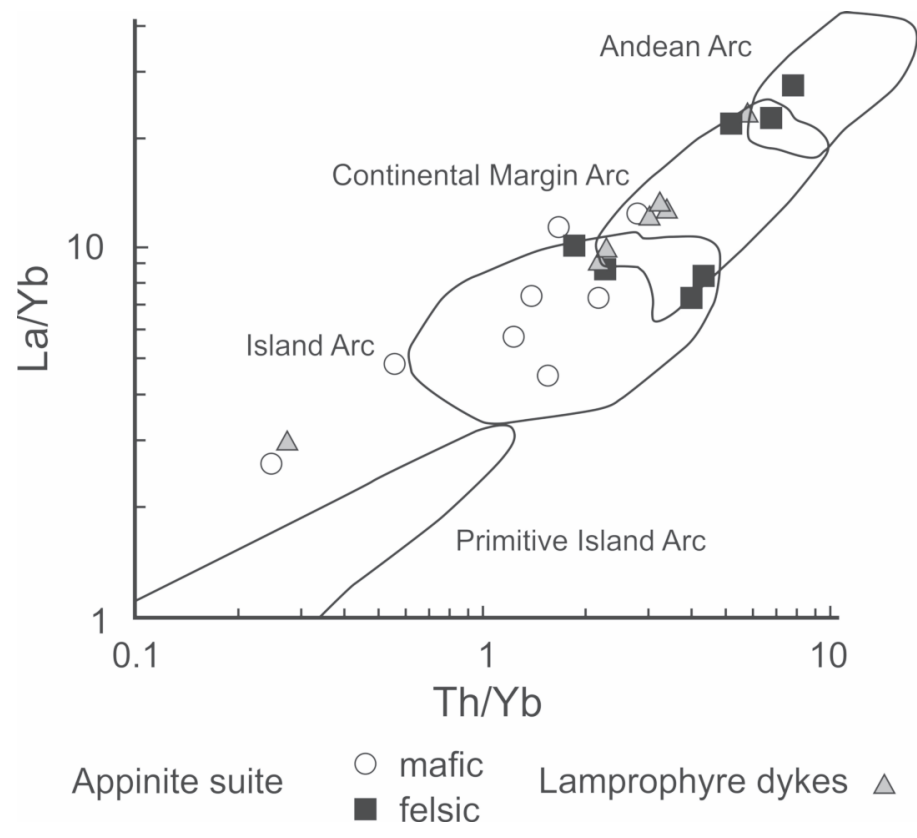

Figure 13. Log-log plot of $\mathrm{La} / \mathrm{Yb}$ vs Th/ $\mathrm{Yb}$ (after Condie 1989) for the appinite suite rocks of Donegal.

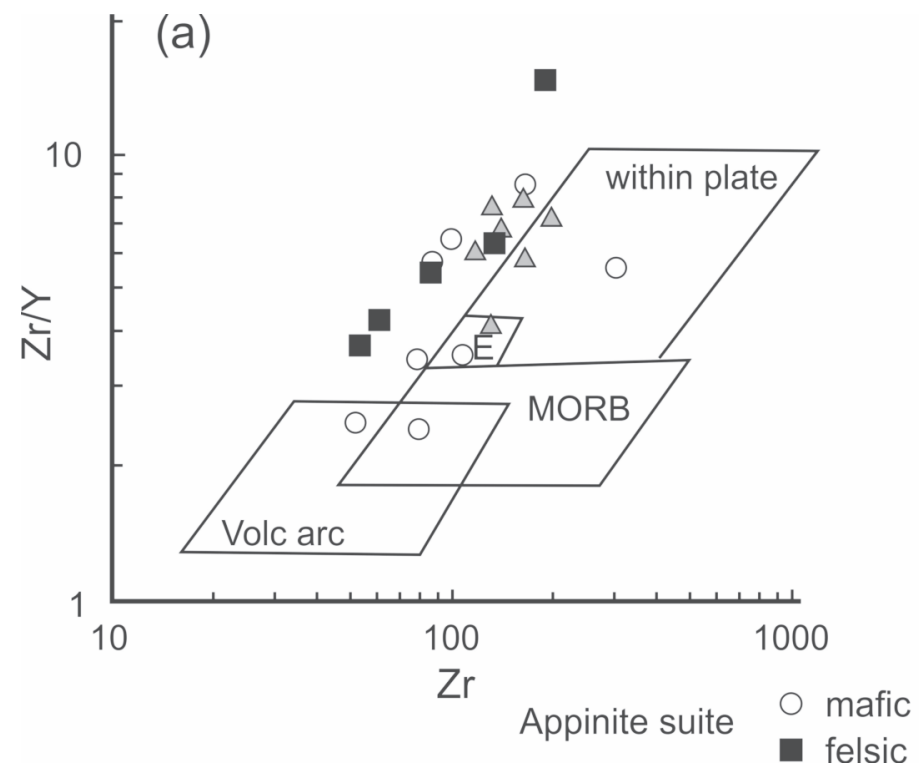

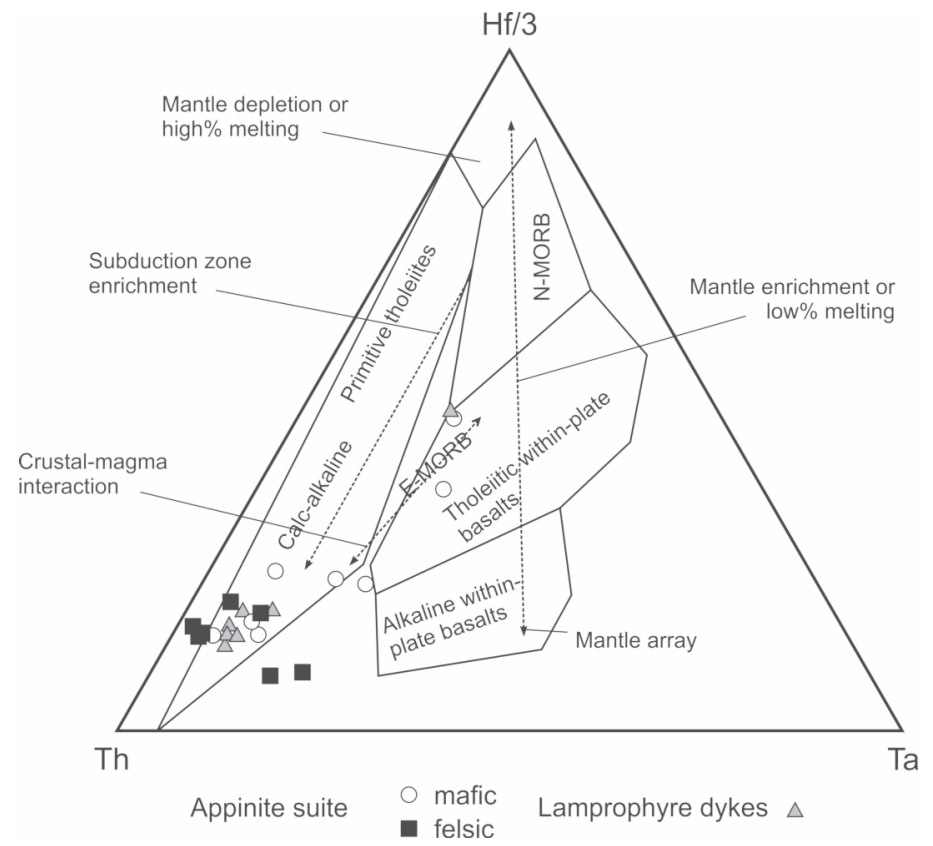

Figure 14. Triangular Hf/3-Ta-Th diagram (after Wood et al. 1979) for the appinite suite rocks of Donegal.

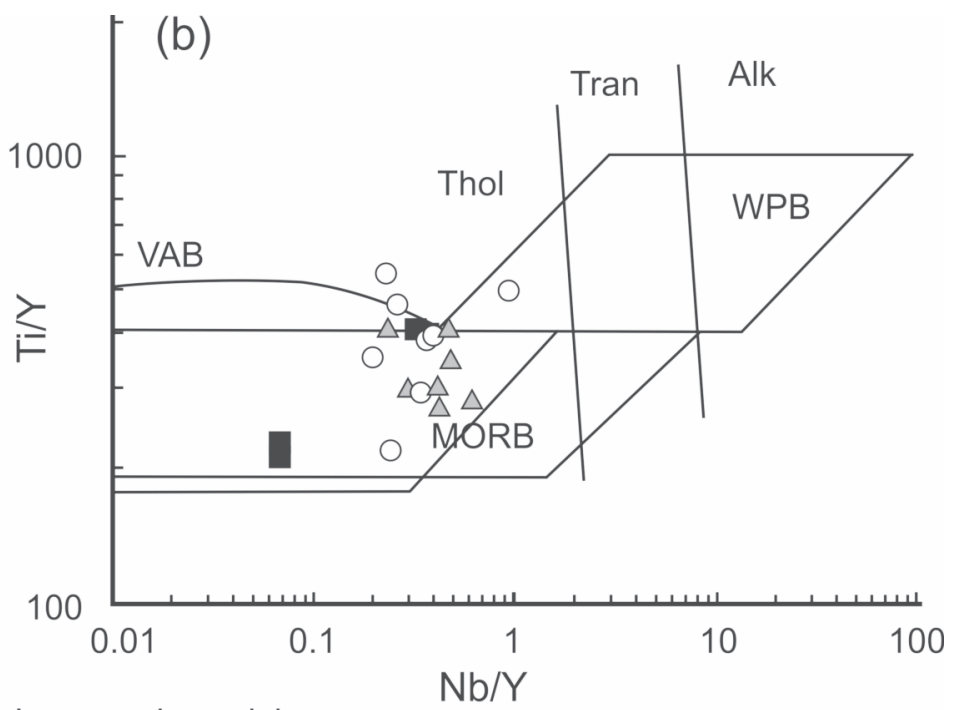

Lamprophyre dykes $\triangle$

Figure 15. Zr vs Zr/Y discrimination diagram (after Pearce and Norry 1979) for the appinite suite rocks of Donegal. MORB (mid-ocean ridge basalt); E (enriched mid-ocean ridge basalt); VAB (volcanic arc basalt); WPB (within-plate basalt).

which slab break-off magmatism has been inferred (Ghani and Atherton 2008; Oliver et al. 2008; Neilson et al. 2009). Models proposed to account for appinitic and lamprophyric magmas in collisional settings ascribe the heat source to asthenospheric upwelling caused either by extensional tectonics associated with late orogenic events (Seyítoğlu and Scott 1996), such as lithospheric delamination, or by slab break-off (Dilek and Altunkaynak 2009). In both these scenarios, asthenospheric upwelling results in coeval melting of the overlying metasomatized SCLM and at least partial replacement of the SCLM (O'Reilly and Griffin 2006) by younger juvenile mantle (Downes 2001).

\section{Regional Implications}

The geochemical data presented here are consistent with previously published data for coeval post-collisional appinite plutons and lamprophyre dykes in the Scottish Highlands (Fowler 1988) whose emplacement also immediately preceded the emplacement of Caledonian granite plutons. These similarities suggest that processes responsible have regional significance. The origin of the rocks of the appinite suite and lamprophyre dykes in the Caledonides has been related specifically to the closure of the Iapetus Ocean, which was immediately followed by subduction of Avalonia beneath Laurentia (Bowes and Košler 1993). Slab break-off is likely to have been a conse- 
Table 2. Sm-Nd isotope, $\varepsilon \mathrm{Nd}$ and $\mathrm{T}_{\mathrm{DM}}$ age data for the mafic and intermediate-felsic rocks of the appinite suite and coeval lamprophyre dykes peripheral to the Ardara pluton, Donegal, Ireland.

\begin{tabular}{|c|c|c|c|c|c|c|c|c|}
\hline Sample & Nd (ppm) & Sm (ppm) & ${ }^{147} \mathrm{Sm} /{ }^{144} \mathrm{Nd}$ & ${ }^{143} \mathrm{Nd} /{ }^{144} \mathrm{Nd}$ & $2 \mathrm{~s}$ & $\varepsilon N d(0 \mathrm{Ma})$ & $\varepsilon N d(435 \mathrm{Ma})$ & $\mathbf{T}_{\mathrm{DM}}$ \\
\hline DWH-003 & 21.71 & 4.38 & 0.1219 & 0.512347 & 6 & -5.7 & -1.5 & 1156 \\
\hline DMH-003 & 35.84 & 6.86 & 0.1158 & 0.512454 & 7 & -3.6 & 0.9 & 922 \\
\hline FEL-001 & 18.41 & 4.07 & 0.1335 & 0.512478 & 7 & -3.1 & 0.4 & 1076 \\
\hline LMB-009 & 31.75 & 6.43 & 0.1225 & 0.512318 & 7 & -6.2 & -2.1 & 1210 \\
\hline LBB-002 & 24.05 & 4.88 & 0.1226 & 0.512257 & 7 & -7.4 & -3.3 & 1311 \\
\hline INK-004 & 20.25 & 5.14 & 0.1536 & 0.512365 & 5 & -5.3 & -2.9 & 1710 \\
\hline AGR-001 & 17.90 & 3.67 & 0.1239 & 0.512381 & 6 & -5.0 & -1.0 & 1124 \\
\hline GLE-001 & 14.76 & 3.65 & 0.1496 & 0.512336 & 7 & -5.9 & -3.3 & 1673 \\
\hline GLE-004 & 21.18 & 5.25 & 0.1500 & 0.512339 & 7 & -5.8 & -3.2 & 1676 \\
\hline LBB-003 & 22.03 & 4.71 & 0.1294 & 0.512603 & 6 & -0.7 & 3.1 & 805 \\
\hline INK-008 & 8.59 & 1.99 & 0.1400 & 0.512231 & 8 & -7.9 & -5.8 & 1673 \\
\hline FEL-005 & 20.39 & 3.61 & 0.1071 & 0.512212 & 7 & -8.3 & -3.3 & 1189 \\
\hline
\end{tabular}

$\left({ }^{143} \mathrm{Nd} /{ }^{144} \mathrm{Nd}\right)$ is adjusted from the deviation to JNdi-1 Standard (accepted valve $\left.=0.512115\right)$, mean measured value of the standard gives: ${ }^{143} \mathrm{Nd} /{ }^{144} \mathrm{Nd}(0.512105)$ Std $(0.000008) \mathrm{n}(22)$

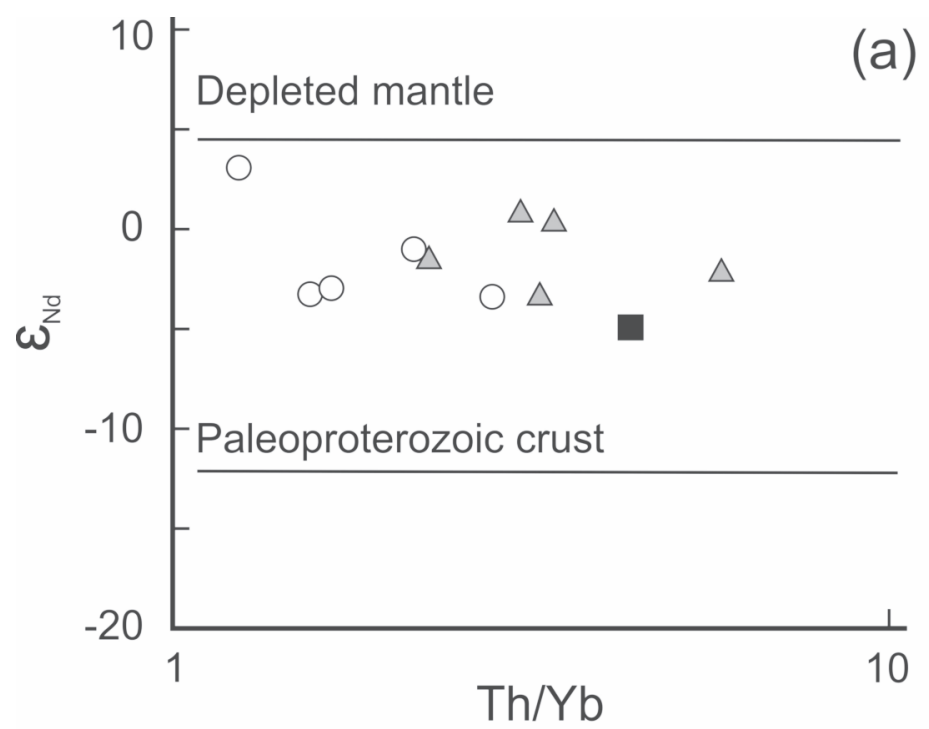

$\begin{array}{ll}\text { Appinite suite } \quad & \text { mafic } \\ & \text { felsic }\end{array}$

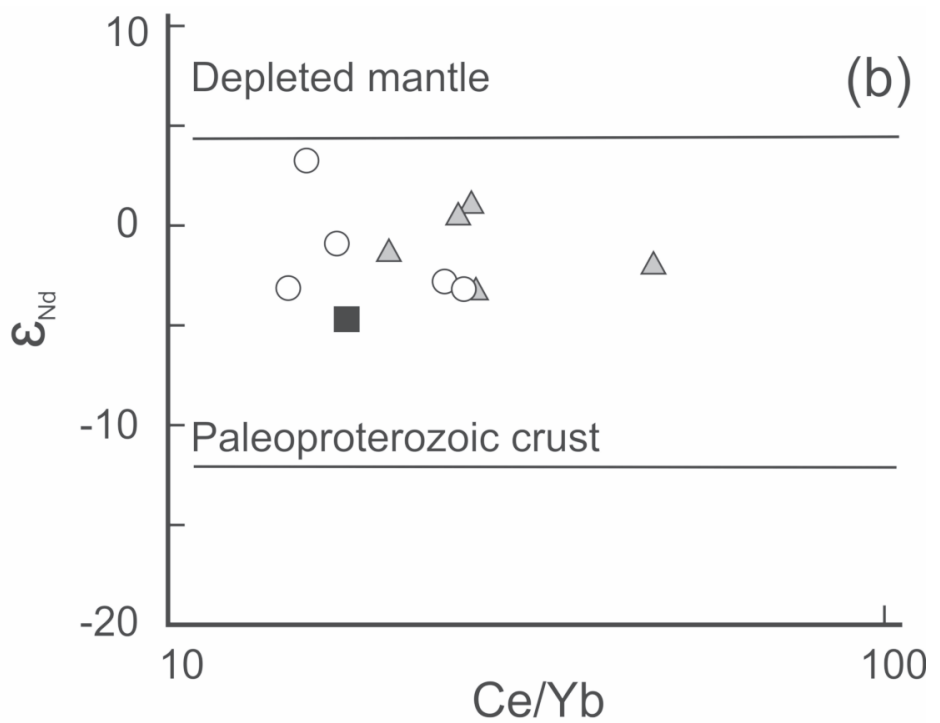

Lamprophyre dykes $\triangle$

Figure 16. Nd isotope evolution diagram for the appinite suite rocks of Donegal. Values shown on the depleted mantle curve are $\mathrm{T}_{\mathrm{DM}}$ ages (DePaolo 1981, 1988).

quence of this event. The magmatic association related to this collision (high-K, calc-alkaline, lamprophyric compositions) and the accompanying granitoid magmatism are best interpreted as direct responses to slab-breakoff, an association recently suggested for some late-stage Cordilleran batholiths (e.g. Hildebrand and Whalen 2014a, b). Within the Caledonian orogen in Britain, the association in time and space of appinitic, lamprophyric and voluminous granitic magmas is one in which the mantle components are chemically and isotopically similar and the magmas of all three rock groups are genetically related (Rock and Hunter 1987; Fowler and Henney 1996).

The felsic components include large batholiths that were probably derived by fractionation of shoshonitic magma
(Fowler 1988). Other appinite suites include some, but not all, of these features (Murphy 2013). Some common tectonic traits of appinitic rocks include a tendency to be emplaced soon after the cessation of subduction, and the important role of deep crustal faults as conduits for magmas of various compositions to rise towards the surface. These conduits provide the setting for magmas of diverse composition to mix and mingle (Murphy 2013). The magmas are quite similar to those of lamprophyre dykes and, together with ultrapotassic magma, are considered to have a parental source in potassium-rich phlogopite-bearing mantle. The appinitic and lamprophyric rocks of Donegal may therefore be an example of the products of collisional asthenospheric upwelling that occurred in this area 


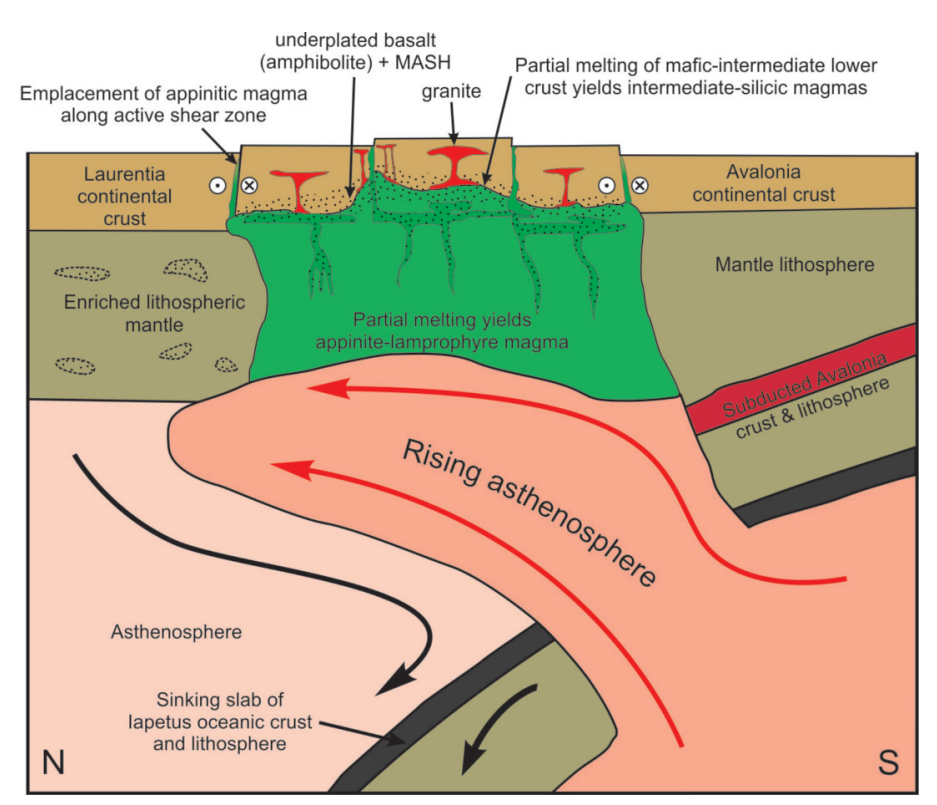

Figure 17. Schematic illustration (modified after Neilson et al. 2009) of a model for magmatism in the Caledonides of Scotland and NW Ireland relating the origin of appinite magma through slab break-off and the consequent upwelling of hot asthenosphere. This upwelling is thought to have caused partial melting of the lithospheric mantle, producing an appinitic-lamprophyre mafic layer that underplated the crust and initiated the production of voluminous granitoid magma. Magma ascent was likely facilitated by major faults (e.g. Jacques and Reavy 1994).

during the Caledonian orogeny. Whether these occurrences can be attributed to an orogen-wide delamination event or to localized zones where slab break-off occurred would require further investigation.

\section{ACKNOWLEDGEMENTS}

This study was made possible by an NSERC (Canada) Discovery grants and a Hadyn Williams Fellowship to JBM at Curtin University. LBG and RDN also acknowledge significant support from Ohio University. We thank David Chew and Pat Meere for constructive and informative reviews, Rob Raeside for very thorough copy-editing and Stephen Johnston for editorial handling. The authors are also indebted to Dave Moecher, University of Kentucky, who provided the microprobe data and X-ray images of the amphibole and to Sherri Strong (Memorial University) and the analytical scientists at the ACME labs in Vancouver, BC, for their role in the geochronological and geochemical aspects of the study.

\section{REFERENCES}

Arculus, R.J., 2003, Use and abuse of the terms calcalkaline and calcalkalic: Journal of Petrology, v. 44, p. 929-935, https://doi.org/10.1093/petrology/44.5.929.

Atherton, M.P., and Ghani, A.A., 2002, Slab breakoff: a model for Caledonian, Late Granite syn-collisional magmatism in the orthotectonic (metamorphic) zone of Scotland and Donegal, Ireland: Lithos, v. 62, p. 65-85, https://doi.org/ 10.1016/S0024-4937(02)00111-1.

Berger, A.R., 1971, The origin of banding in the Main Donegal Granite, N.W. Ireland: Geological Journal, v. 7, p. 347-358, https://doi.org/10.1002/ gj.3350070210.

Bowes, D.R., and Košler, J., 1993, Geochemical comparison of the subvolcanic appinite suite of the British Caledonides and the durbachite suite of the Central European Hercynides: Evidence for associated shoshonitic and granitic magmatism: Mineralogy and Petrology, v. 48, p. 47-63, https://doi.org/10.1007/ BF01164908.

Bowes, D.R., and McArthur, A.C., 1976, Nature and genesis of the appinite suite: Krystalinikum, v. 12, p. 31-46.

Castro, A., Corretge, L.G., de la Rosa, J.D., Enrique, P., Martinez, F.J., Pascual, E., Lago, M., Arranz, E., Gale, C., Fernández, C., Donaire, T., and López, S., 2002, Palaeozoic magmatism, in Gibbons, W., and Moreno, T., eds., The Geology of Spain: The Geological Society of London, p. 117-153.

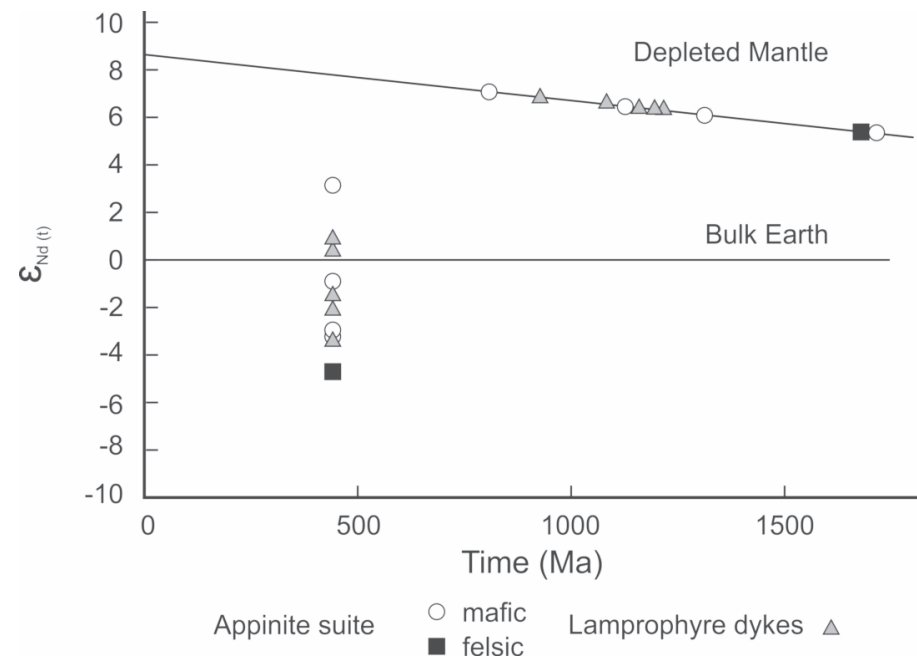

Figure 18. Plots of (a) $\varepsilon \mathrm{Nd}$ vs $\mathrm{Th} / \mathrm{Yb}$, and (b) $\varepsilon \mathrm{Nd}$ vs $\mathrm{Ce} / \mathrm{Yb}$ (hypothetical evolution of Paleoproterozoic crust shown as reference).

Chew, D.M., and Strachan, R.A., 2014, The Laurentian Caledonides of Scotland and Ireland, in Corfu, F., Gasser, D., and Chew, D.M., eds., New perspectives on the Caledonides of Scandinavia and related area: Geological Society, London, Special Publications, v. 390, p. 45-91, https://doi.org/10.1144/SP390.16.

Condie, K.C., 1989, Geochemical changes in basalts and andesites across the Archean-Proterozoic boundary: identification and significance: Lithos, v. 23, p. $1-18$.

Condon, D.J., Bowring, S.A., Pitcher, W.S., and Hutton, D.W., 2004, Rates and tempo of granitic magmatism: a $\mathrm{U}-\mathrm{Pb}$ geochronological investigation of the Donegal Batholith (Ireland): Geological Society of America, Abstracts with Programs, v. 46, p. 406.

Condon, D.J., Hodges, K.V., Alsop, G.I., and White, A., 2006, Laser ablation ${ }^{40} \mathrm{Ar} /{ }^{39} \mathrm{Ar}$ dating of metamorphic fabrics in the Caledonides of north Ireland: Journal of the Geological Society, v. 163, p. 337-345, https://doi.org/10.1144/ 0016-764904-066.

Cooper, M.R., Crowley, Q.G., Hollis, S.P., Noble, S.R., and Henney, P.J., 2013, A U$\mathrm{Pb}$ age for the Late Caledonian Sperrin Mountains minor intrusions suite in the north of Ireland: timing of slab break-off in the Grampian terrane and the significance of deep-seated, crustal lineaments: Journal of the Geological Society, v. 170, p. 603-614, https://doi.org/10.1144/jgs2012-098.

Dalrymple, G.B., Alexander Jr., E.C., Lanphere, M.A., and Kraker, G.P., 1981, Irradiation of samples for ${ }^{40} \mathrm{Ar} /{ }^{30} \mathrm{Ar}$ dating using the Geological Survey TRIGA reactor: United States Geological Survey, Professional Paper, 1176, 55 p., https://doi.org/10.3133/pp1176.

DePaolo, D.J., 1981, Neodymium isotopes in the Colorado Front Range and crustmantle evolution in the Proterozoic: Nature, v. 291, p. 193-196, https://doi.org/10.1038/291193a0.

DePaolo, D.J. 1988, Neodymium Isotope Geochemistry: An Introduction: Springer Verlag, New York, 187 p., https://doi.org/10.1007/978-3-642-48916-7.

Dewey, J.F., and Shackleton, R.M., 1984, A model for the evolution of the Grampian tract in the early Caledonides and Appalachians: Nature, v. 312, p. 115-121, https://doi.org/10.1038/312115a0.

Dilek, Y., and Altunkaynak, S., 2009, Geochemical and temporal evolution of Cenozoic magmatism in western Turkey: mantle response to collision, slab break-off, and lithospheric tearing in an orogenic belt: Geological Society, London, Special Publications, v. 311, p. 213-233, http://dx.doi.org/10.1144/SP311.8.

Dodson, M.H., 1973, Closure temperature in cooling geochronological and petrological systems: Contributions to Mineralogy and Petrology, v. 40, p. 259-274, https://doi.org/10.1007/BF00373790.

Downes, H., 2001, Formation and modification of the shallow sub-continental lithospheric mantle: a review of geochemical evidence from ultramafic xenolith suits and tectonically emplaced ultramafic massifs of Western and Central Europe: Journal of Petrology, v. 42, p. 233-250, https://doi.org/10.1093/ petrology/42.1.233.

Elsdon, R., and Todd, S.P., 1989, A composite spessartite-appinite intrusion from Port-na-Blagh, County Donegal, Ireland: Geological Journal, v. 24, p. 97-112, https://doi.org/10.1002/gj.3350240203.

Fowler, M.B., 1988, Ach'uaine hybrid appinite pipes: Evidence for mantle-derived shoshonitic parent magmas in Caledonian granite genesis: Geology, v. 16, p. 
1026-1030, https://doi.org/10.1130/0091-7613(1988)016<1026:AUHAPE> 2.3.CO;2.

Fowler, M.B., and Henney, P.J., 1996, Mixed Caledonian appinite magmas: implications for lamprophyre fractionation and high $\mathrm{Ba}-\mathrm{Sr}$ granite genesis: Contributions to Mineralogy and Petrology, v. 126, p. 199-215, https://doi.org/ $10.1007 / \mathrm{s} 004100050244$.

Fowler, M.B., Kocks, H., Darbyshire, D.P.F., and Greenwood, P.B., 2008, Petrogenesis of high $\mathrm{Ba}-\mathrm{Sr}$ plutons from the Northern Highlands Terrane of the British Caledonian Province: Lithos, v. 105, p. 129-148, https://doi.org/10.1016/ j.lithos.2008.03.003.

French, J.W., 1966, Appinitic intrusions clustered around the Ardara Pluton, County Donegal: Proceedings of the Royal Irish Academy, v. B64, p. 303-322.

French, W.J., 1976, The origin of leucodiorites associated with the appinitic intrusions of County Donegal: Proceedings of the Yorkshire Geological Society, v. 41, p. 107-126, https://doi.org/10.1144/pygs.41.1.107.

Geological Survey of Ireland, 2014, Bedrock Geology of Ireland, 1:1,000,000 scale (map).

Ghani, A.A., and Atherton, M.P., 2008, The chemical character of the Late Caledon ian Donegal Granites, Ireland, with comments on their genesis: Earth and Environmental Science Transactions of the Royal Society of Edinburgh, v. 97, p. 437-454, https://doi.org/10.1017/S0263593300001553.

Goldstein, S.L., O’Nions, R.K., and Hamilton, P.J., 1984, A Sm-Nd isotopic study of atmospheric dusts and particulates from major river systems: Earth and Planetary Science Letters, v. 70, p. 221-236, https://doi.org/10.1016/0012 821X(84)90007-4.

Hall, A., 1967, The chemistry of appinitic rocks associated with the Ardara pluton, Donegal, Ireland: Contributions to Mineralogy and Petrology, v. 16, p. 156-171, https://doi.org/10.1007/BF00372795

Halliday, A.N., Aftalion, M., and Leake, B.E., 1980, A revised age for the Donegal granites: Nature, v. 284, p. 542-543, https://doi.org/10.1038/284542a0.

Hamidullah, S., and Bowes, D.R., 1987, Petrogenesis of the appinite suite, Appin District, Western Scotland: Acta Universitatis Carolinae, Geologica, v. 4, p. 295 396.

Harmon, R.S., Halliday, A.N., Clayburn, J.A.P., and Stephens, W.E., 1984, Chemical and isotopic systematics of the Caledonian intrusions of Scotland and Northern England: a guide to magma source region and magma-crust interaction: Philosophical Transactions of the Royal Society London A, v. 310, p. 709-742, https://doi.org/10.1098/rsta.1984.0016.

Harrison, T.M., 1982, Diffusion of ${ }^{40} \mathrm{Ar}$ in hornblende: Contributions to Mineralogy and Petrology, v. 78, p. 324-331, https://doi.org/10.1007/BF00398927.

Hildebrand, R.S., and Whalen, J.B., 2014a, Arc and slab-failure magmatism in Cordilleran batholiths I-the Cretaceous Coastal batholith of Peru and its role in South American orogenesis and hemispheric subduction flip: Geoscience Canada, v. 41, p. 255-282, http://dx.doi.org/10.12789/geocanj.2014.41.047.

Hildebrand, R.S., and Whalen, J.B., 2014b, Arc and slab-failure magmatism in Cordilleran batholiths II-the Cretaceous Peninsular Ranges batholith of Southern and Baja California: Geoscience Canada, v. 41, p. 399-458, http://dx.doi.org/10.12789/geocanj.2014.41.059.

Hildebrand, R.S., Whalen, J.B., and Bowring, S.A., 2018, Resolving the crustal composition paradox by 3.8 billion years of slab failure magmatism and collisional recycling of continental crust: Tectonophysics, v. 734-735, p. 69-88, https://doi.org/10.1016/j.tecto.2018.04.001

Hutton, D.H.W., 1982, A tectonic model for the emplacement of the Main Donegal Granite, NW Ireland: Journal of the Geological Society, v. 139, p. 615-631, https://doi.org/10.1144/gsigs.139.5.0615.

Hutton, D.H.W., and Alsop, G.I., 1996, The Caledonian strike-swing and associated lineaments in NW Ireland and adjacent areas: sedimentation, deformation and igneous intrusion patterns: Journal of the Geological Society, v. 153, p. 345360, https://doi.org/10.1144/gsigs.153.3.0345.

Jacques, J.M., and Reavy, R.J., 1994, Caledonian plutonism and major lineaments in the SW Scottish Highlands: Journal of the Geological Society, v. 151, p. 955 969, https://doi.org/10.1144/gsigs.151.6.0955.

Kerrick, D.M., 1987, Fibrolite in contact aureoles of Donegal, Ireland: American Mineralogist, v. 72, p. 240-254.

Kirkland, C.L., Alsop, G.I., and Prave, A.R., 2008, The brittle evolution of a major strike-slip fault associated with granite emplacement: a case study of the Leannan Fault, NW Ireland: Journal of the Geological Society, v. 165, p. 341-352, https://doi.org/10.1144/0016-76492007-064

Kirkland, C.L., Alsop, G.I., Daly, J.S., Whitehouse, M.J., Lam, R., and Clark, C., 2013 , Constraints on the timing of Scandian deformation and the nature of a buried Grampian terrane under the Caledonides of northwestern Ireland: Journal of the Geological Society, v. 170, p. 615-625, https://doi.org/10.1144/jgs2012 106.
Kuiper, K.F., Deino, A., Hilgen, F.J., Krijgsman, W., Renne, P.R., and Wijbrans, J.R., 2008 , Synchronizing rock clocks of earth history: Science, v. 320 , p. $500-504$, https://doi.org/10.1126/science.1154339.

Leake, B.E., 1978, Nomenclature of amphiboles: Canadian Mineralogist, v. 16, p. 501-520.

Leake, B.E., Woolley, A.R., Birch, W.D., and Burke, E.A.J., 2004, Nomenclature of amphiboles: additions and revisions to the International Mineralogical Association's amphibole nomenclature: Mineralogical Magazine, v. 68, p. 209-215, http://dx.doi.org/10.1180/0026461046810182.

Lee, J.-Y., Marti, K., Severinghaus, J.P., Kawamura, K., Hee-Soo, Yoo, Lee, J.B., and Kim, J.S., 2006, A redetermination of the isotopic abundances of atmospheric Ar: Geochimica et Cosmochimica Acta, v. 70, p. 4507-4512, https://doi.org/ 10.1016/j.gca.2006.06.1563.

Ludwig, K.R., 2008, User's Manual for ISOPLOT 3.60 - A geochronological toolkit for Microsoft Excel: Berkeley Geochronological Centre Special Publication Number 4, 54 p.

Macdonald, R., Rock, N.M.S., Rundle, C.C., and Russell, O.J., 1986, Relationships between late Caledonian lamprophyric, syenitic, and granitic magmas in a differentiated dyke, southern Scotland: Mineralogical Magazine, v. 50, p. 547-557, https://doi.org/10.1180/minmag.1986.050.358.01

McDougall, I., and Harrison, T.M., 1988, Geochronology and Thermochronology by the ${ }^{40} \mathrm{Ar} /{ }^{39} \mathrm{Ar}$ Method: Oxford University Press, NY, $212 \mathrm{p}$.

McDougall, I., and Wellman, P., 2011, Calibration of GA1550 biotite standard for $\mathrm{K} / \mathrm{Ar}$ and ${ }^{40} \mathrm{Ar} /{ }^{39} \mathrm{Ar}$ dating: Chemical Geology, v. 280, p. 19-25, https://doi.org/10.1016/j.chemgeo.2010.10.001

Min, K., Mundil, R., Renne, P.R., and Ludwig, K.R., 2000, A test for systematic errors in ${ }^{40} \mathrm{Ar} /{ }^{39} \mathrm{Ar}$ geochronology through comparison with $\mathrm{U} / \mathrm{Pb}$ analysis of a 1.1 Ga rhyolite: Geochimica et Cosmochimica Acta, v. 64, p. 73-98, https://doi.org/10.1016/S0016-7037(99)00204-5.

Mitchell, R.H., 1995, Melting experiments on a sanidine phlogopite lamproite at 4 $7 \mathrm{GPa}$ and their bearing on the source of lamproitic magmas: Journal of Petrology, v. 36, p. 1455-1474, https://doi.org/10.1093/petrology/36.5.1455.

Miyashiro, A., 1974, Volcanic rock series in island arcs and active continental margins: American Journal of Science, v. 274, p. 321-355, https://doi.org/ 10.2475/ajs.274.4.321

Murphy, J.B., 2013, Appinite suites: A record of the role of water in the genesis, transport, emplacement and crystallization of magma: Earth-Science Reviews, v. 119, p. 35-59, https://doi.org/10.1016/j.earscirev.2013.02.002.

Murphy, J.B., and Hynes, A.J., 1990, Tectonic control on the origin and orientation of igneous layering: an example from the Greendale Complex, Antigonish Highlands, Nova Scotia, Canada: Geology, v. 18, p. 403-406, https://doi.org/ 10.1130/0091-7613(1990)018<0403:TCOTOA>2.3.CO;2.

Neilson, J.C., Kokelaar, B.P., and Crowley, Q.G., 2009, Timing, relations and cause of plutonic and volcanic activity of the Siluro-Devonian post-collision magmatic episode in the Grampian Terrane, Scotland: Journal of the Geological Society, v. 166, p. 545-561, https://doi.org/10.1144/0016-76492008-069.

O’Connor, P.J., Long, C.B., Kennan, P.S., Halliday, A.N., Max, M.D., and Roddick, J.C., 1982, Rb-Sr isochron study of the Thorr and Main Donegal Granites, Ireland: Geological Journal, v. 17, p. 279-295, https://doi.org/10.1002/ gj.3350170403

O’Connor, P.J., Long, C.B., and Evans, J.A., 1987, Rb-Sr whole-rock isochron studies of the Barnesmore and Fanad plutons, Donegal, Ireland: Geological Journal, v. 22, p. 11-23, https://doi.org/10.1002/gj.3350220103.

Oliver, G.J.H., 2001, Reconstruction of the Grampian episode in Scotland: its place in the Caledonian Orogeny: Tectonophysics, v. 332, p. 23-49, https://doi.org/ 10.1016/S0040-1951(00)00248-1.

Oliver, G.J.H., Wilde, S.A., and Wan, Y., 2008, Geochronology and geodynamics of Scottish granitoids from the late Neoproterozoic break-up of Rodinia to Palaeozoic collision: Journal of the Geological Society, v. 165, p. 661-674, https://doi.org/10.1144/0016-76492007-105.

Onstott, T.C., Phillips, D., and Pringle-Goodell, L., 1991, Laser microprobe measurement of chlorine and argon zonation in biotite: Chemical Geology, v. 90, p. 145-168, https://doi.org/10.1016/0009-2541(91)90040-X

O'Reilly, S.Y., and Griffin, W.L., 2006, Imaging global chemical and thermal heterogeneity in the subcontinental lithospheric mantle with garnets and xenoliths: Geophysical implication: Tectonophysics, v. 416, p. 289-309, https://doi.org/ 10.1016/j.tecto.2005.11.014.

Pearce, J.A., 1982, Trace element characteristics of lavas from destructive plate boundaries, in Thorpe, R.S., ed., Andesites: Wylie and Sons, p. 525-548.

Pearce, J.A., 1983, Role of the sub-continental lithosphere in magma genesis at active continental margins, in Hawkesworth, C.J., and Norry, M.J., eds., Continental basalts and mantle xenoliths: Shiva Publications, Nantwich, Cheshire, p. $230-249$. 
Pearce, J.A., 1996, A user's guide to basaltic discrimination diagrams, in Wyman, D.A., ed., Trace Element Geochemistry of Volcanic Rocks: Applications for Massive Sulphide Exploration: Geological Association of Canada Short Course Notes, 12, p. 79-113.

Pearce, J.A., and Norry, M.J., 1979, Petrogenetic implications of Ti, Zr, Y, and Nb variations in volcanic rocks: Contributions to Mineralogy and Petrology, v. 69, p. 33-47, https://doi.org/10.1007/BF00375192.

Pe-Piper, G., 1988, Calcic amphiboles of mafic rocks of the Jeffers Brook plutonic complex, Nova Scotia, Canada: American Mineralogist, v. 73, p. 993-1006.

Pitcher, W.S., Berger, A.R., 1972, The Appinite suite: basic rocks genetically associated with granite, in Pitcher, W.S., and Berger, A.R., eds., The Geology of Donegal. A Study of Granite Emplacement and Unroofing: John Wiley and Sons Ltd, New York, p. 143-168.

Pitcher, W.S., and Read, H.H., 1960, The aureole of the Main Donegal Granite: Quarterly Journal of the Geological Society, v. 116, p. 1-36, https://doi.org/ 10.1144/gsigs.116.1.0001.

Platten, I.M., 1991, Zoning and layering in diorites of the scottish caledonian appinite suite: Geological Journal, v. 26, p. 329-348, https://doi.org/10.1002/ g).3350260406.

Price, A.R., 1997, Multiple sheeting as a mechanism of pluton construction: the main Donegal granite, NW Ireland: Unpublished PhD thesis, Durham University, Durham, UK, 394 p.

Rock, N.M.S., 1991, Lamprophyres: Blackie, Glasgow, p. 265-285.

Rock, N.M.S., and Hunter, R.H., 1987, Late Caledonian dyke-swarms of northern Britain: spatial and temporal intimacy between lamprophyric and granitic magmatism around the Ross of Mull pluton, Inner Hebrides: Geologische Rundschau, v. 76, p. 805-826, https://doi.org/10.1007/BF01821065.

Roddick, J.C., 1983, High precision intercalibration of ${ }^{40} \mathrm{Ar} /{ }^{39} \mathrm{Ar}$ standards: Geochimica et Cosmochimica Acta, v. 47, p. 887-898, https://doi.org/ 10.1016/0016-7037(83)90154-0.

Rogers, G., and Dunning, G.R., 1991, Geochronology of appinitic and related granitic magmatism in the W Highlands of Scotland: constraints on the timing of transcurrent fault movement: Journal of the Geological Society, v. 148, p. 17-27, https://doi.org/10.1144/gsigs.148.1.0017.

Salmon, S., 1998, The plutonic igneous complex at Sorel Point, Jersey, Channe Islands: A high level multi-magma assemblage: Geological Journal, v. 33, p. $17-$ 35, https://doi.org/10.1002/(SICI)1099-1034(199801/03)33:1<17::AID GJ757>3.0.CO;2-E.

Seyítoğlu, G., and Scott, B.C., 1996, The cause of N-S extensional tectonics in western Turkey: Tectonic escape vs back-arc spreading vs orogenic collapse: Journal of Geodynamics, v. 22, p. 145-153, https://doi.org/10.1016/0264 3707(96)00004-X

Shervais, J.W., 1982, Ti-V plots and the petrogenesis of modern ophiolitic lavas: Earth and Planetary Science Letters, v. 59, p. 101-118, https://doi.org/ 10.1016/0012-821X(82)90120-0.

Siegesmund, S., and Becker, J.K., 2000, Emplacement of the Ardara pluton (Ireland): new constraints from magnetic fabrics, rock fabrics and age dating: International Journal of Earth Sciences, v. 89, p. 307-327, https://doi.org/10.1007/ s005310000088.

Spell, T.L., and McDougall, I., 2003, Characterization and calibration of ${ }^{40} \mathrm{Ar} /{ }^{39} \mathrm{Ar}$ dating standards: Chemical Geology, v. 198, p. 189-211, https://doi.org/ 10.1016/S0009-2541(03)00005-6.

Stevenson, C.T.E., Hutton, D.H.W., and Price, A.R., 2008, The Trawenagh Bay Granite and a new model for the emplacement of the Donegal Batholith: Earth and Environmental Science Transactions of The Royal Society of Edinburgh, v. 97, 455-477, https://doi.org/10.1017/S0263593300001565.

Sun, S.-s., and McDonough, W.F., 1989, Chemical and isotopic systematics of oceanic basalts: implications for mantle composition and processes, in Saunders, A.D., and Norry, M.J., eds., Magmatism in the Oceanic Basins: Geological Society, London, Special Publications, v. 42, p. 313-345, https://doi.org/10.1144/ GSL.SP.1989.042.01.19

Thompson, R.N., and Fowler, M.B., 1986, Subduction-related shoshonitic and ultrapotassic magmatism: a study of Siluro-Ordovician syenites from the Scottish Caledonides: Contributions to Mineralogy and Petrology, v. 94, p. 507-522, https://doi.org/10.1007/BF00376342.

Todd, S.P., Murphy, F.C., and Kennan, P.S., 1991, On the trace of the Iapetus suture in Ireland and Britain: Journal of the Geological Society, v. 148, p. 869-880, https://doi.org/10.1144/gsigs.148.5.0869.

van Staal, C.R., Dewey, J.F., Mac Niocaill, C., and McKerrow, W.S., 1998, The Cambrian-Silurian tectonic evolution of the northern Appalachians and British Caledonides: history of a complex, west and southwest Pacific-type segment of Iapetus, in Blundell, D.J., and Scott, A.C., eds., Lyell: The Past is the Key to the Present: Geological Society, London, Special Publications, v. 143, p. 197-242,
https://doi.org/10.1144/GSL.SP.1998.143.01.17.

Vernon, R.H., and Paterson, S.R., 1993, The Ardara pluton, Ireland: deflating an expanded intrusion: Lithos, v. 31, p. 17-32, https://doi.org/10.1016/0024 4937(93)90030-G

von Blackenburg, F., and Davies, J.H., 1995, Slab breakoff: A model for syncollisional magmatism and tectonics in the Alps: Tectonics, v. 14, p. 120-131, https://doi.org/10.1029/94TC02051.

Walker, F., 1927, VII. - The Igneous Geology of Ardsheal Hill, Argyllshire: Earth and Environmental Science Transactions of the Royal Society of Edinburgh, v. 55, p. 147-157, https://doi.org/10.1017/S0080456800016288.

Winchester, J.A., and Floyd, P.A., 1977, Geochemical discrimination of different magma series and their differentiation products using immobile elements: Chemical Geology, v. 20, p. 325-343, https://doi.org/10.1016/00092541(77)90057-2.

Wood, D.A., Joron, J.-L., and Treuil, M., 1979, A re-appraisal of the use of trace elements to classify and discriminate between magma series erupted in different tectonic settings: Earth and Planetary Science Letters, v. 45, p. 326-336, https://doi.org/10.1016/0012-821X(79)90133-X.

Wright, A.E., and Bowes, D.R., 1979, Geochemistry of the appinite suite, in Harris A.L., Holland, C.H., and Leake, B.E., eds., The Caledonides of the British Isles - Reviewed: Geological Society, London, Special Publications, v. 8, p. 699-704, https://doi.org/10.1144/GSL.SP.1979.008.01.84.

Ye, H.-M., Li, X.-H., Li, Z.-X., and Zhang, C.-L., 2008, Age and origin of high BaSr appinite-granites at the northwestern margin of the Tibet Plateau: implications for early Paleozoic tectonic evolution of the Western Kunlun orogenic belt: Gondwana Research, v. 13, p. 126-138, https://doi.org/10.1016/ j.gr.2007.08.005.

\section{Received July 2018 \\ Accepted as revised December 2018}

*For access to the Murphy et al. (2019) supplementary data files SF-1 to SF-7, please visit the GAC's open source GC Data Repository link for the Andrew Hynes Series: Tectonic Processes at: https://GAC.ca/GC-data-repository/. 